\title{
TRÁFICO DE ESCRAVOS E CONSCIÊNCIA MORAL: O PENSAMENTO ANTIESCRAVISTA DE EPIFÂNIO DE MOIRANS
}

\author{
Fernando Rodrigues Montes D'Oca \\ Instituto Federal Sul-Rio-Grandense/Campus Sapiranga
}

Resumo: Este estudo trata da escravidão negra nos sécs. XVI-XVII, a partir do contexto intelectual da Escolástica Barroca, e apresenta o discurso antiescravista sobre o tráfico de escravos africanos elaborado por Epifânio de Moirans OFMCap (1644-1689) na obra Servi Liberi ("Servos Livres"). Na primeira seção, apresenta-se uma contextualização sobre as discussões e os sistemas da teologia moral dos sécs. XVI-XVII e explica-se que o tema do tráfico se inseriu nessas discussões porque as compras de escravos consistiam nos casos de consciência duvidosa de que se ocupava a teologia moral. A segunda seção trata especificamente do discurso de Moirans sobre o tráfico de escravos. Nesta seção, apresenta-se a condenação de Moirans à escravidão negra a partir do tráfico e explica-se que essa condenação decorre substancialmente do rechaço a alegações, nascidas no interior das discussões da teologia moral, que serviam como salvaguarda das consciências dos envolvidos no tráfico, bem como autorização para a manutenção da compra e venda de escravos.

Palavras-chave: Escravidão Negra, Tráfico de Escravos, Consciência.

\begin{abstract}
This study deals with the Black slavery in the $16^{\text {th }}$ and $17^{\text {th }}$ centuries, from the intellectual context of the Baroque Scholasticism, and it presents the anti-slavery discourse on African slave trade elaborated by Epifanio de Moirans OFMCap (1644-1689) in work Servi Liberi ("Free Slaves"). In the first section, it is presented a contextualization on discussions and systems of moral theology of the $16^{\text {th }}$ and $17^{\text {th }}$ centuries, and it is explained that the issue of trade was inserted into these discussions because the purchases of slaves corresponded to the cases of doubtful conscience of which the moral theology dealt with. The second section deals especially with the Moirans' discourse on slave trade. In this section, it is presented the Moirans' condemnation to the Black slavery from the trade, and it is explained that such condemnation arises substantially from his rejection to allegations, born within the debates of moral theology, that served as a safeguard of the consciences of those involved in the trade, as well as an authorization for the continuity of purchase and sale of slaves.
\end{abstract}

Keywords: Black Slavery, Slave Trade, Conscience.

\section{Introdução}

Durante a Escolástica Barroca, além do debate em torno da escravidão indígena, outro debate chamou a atenção dos intelectuais quinhentistas e seiscentistas: o debate sobre a escravidão negra, que tratava da 
licitude da escravidão civil ou legal (servitus civilis/legalis) a que eram submetidos muitos africanos, bem como da licitude do tráfico de escravos.

Ao contrário do debate sobre a imposição de um regime servil aos aborígenes americanos (que supostamente seriam os bárbaros e escravos naturais de que falara Aristóteles), o debate em torno da escravidão a que eram submetidos os africanos foi menos especulativo, acalorado ou apaixonado. Não estava em questão apoiá-la ou condená-la. Na época, a escravidão civil era uma instituição vigente e incontroversa. Portanto, não era o caso discutir o mérito de sua justiça, mas tão-só a justiça de sua prática. Aparentemente, isso era simples. Contudo, não o foi. De um lado, surgiram controvérsias sobre se as escravizações na África ocorriam em conformidade com o direito, o que motivou autores a escreverem sobre os chamados títulos de justa escravidão e a descreverem os modos (fraudulentos) como os africanos eram reduzidos à escravidão. De outro, surgiram controvérsias sobre a licitude das compras de escravos, o que também motivou autores a escreverem sobre o tráfico, principalmente com vistas a orientarem os cristãos a agirem com correção.

Juntos, os discursos sobre os títulos de justa escravidão e sobre o tráfico de escravos formavam a trama conceitual por trás do pensamento da Escolástica Barroca sobre o problema e o drama da escravidão negra e se constituíam no pano de fundo de abordagem do tema no contexto intelectual ibérico dos sécs. XVI-XVII, de modo que, para sistematizar qualquer estudo sobre a escravidão negra em tal período, é imperativo discerni-los com clareza.

Entre esses dois discursos, o referente ao tráfico sempre se mostrou mais complexo do que o referente aos títulos. Em linhas gerais, pode-se dizer que, quando abordavam o tema dos títulos de escravidão, os autores invariavelmente mencionavam os títulos vigentes ${ }^{1} \mathrm{e}$, posteriormente, valendo-

\footnotetext{
${ }^{1}$ A saber: escravidão por guerra justa (quando o prisioneiro de guerra era poupado pelo inimigo e feito escravo); por venda (quando a necessidade e a miséria obrigavam que alguém vendesse a si próprio ou a seu filho para sobreviver); por nascimento (quando a criança nascia de uma mulher escrava); e escravidão por delito (quando a pena pela prática de um crime era a escravidão). Os três primeiros títulos constavam explicitamente no Corpus iuris civilis (Institutiones, lib. I, tit. 3-8; Digesta, lib. I, tit. 5-6) e nas Siete partidas (Partida IV, tit. 21-23) e eram referidos por quase todos os autores que escreveram sobre a escravidão negra. $O$ último título era reportado pelos autores como usual entre os africanos, mas aplicável limitadamente (para crimes como rapto de donzelas e favorecimento aos sarracenos) entre os cristãos - cf.: MOLINA (De iustitia et iure, tract. II, d. 33, n. 4-13); MERCADO (Summa de tratos y contratos, lib. II, cap. 20). Para detalhes sobre os títulos de escravidão, cf., e.g.: DONOSO (1856, t. 2, p.181-183); DUTILLEUL (1913, col. 508s); AÑOVEROS (2000, p. 85-90.115-120); ANDRÉS-GALLEGO e AÑ̃VEROS (2002, p.105114). Sigo o sistema autor-data apenas para a bibliografia secundária. Refiro as fontes primárias a partir de seu nome e em conformidade com suas próprias divisões internas - pars, liber (lib.), titulus (tit.), tractatus (tract.), disputatio (d.), distinctio (dist.), capitulum/caput (cap.), quaestio (q.), articulus (a.), dubium (dub.), punctum (punct.), entre outras. Como essas divisões já são bastante específicas, limito-me a indicar a paginação apenas nos casos de citação direta das fontes primárias.
} 
se do conhecimento que tinham ou do que ouviam sobre as escravizações na África, pronunciavam-se, a partir de juízos empíricos, sobre a licitude ou não das mesmas. Nesse empenho, os autores posicionaram-se majoritariamente contra a licitude das escravizações, posto que eram notórias as injustiças ocorrentes. E conquanto existam discursos sobre os títulos bastante interessantes e agudos, deve-se reconhecer que a grande questão por trás desses discursos - a licitude ou ilicitude das escravizações - não era das mais complexas ou controversas, o que é sustentando pelo consenso entre os autores de que havia, senão muitas, pelo menos algumas injustiças nas escravizações.

Todavia, essa relativa simplicidade não se verificou nos discursos respectivos ao tráfico de escravos. Por trás desses discursos, há uma variedade de detalhes que não podem ser perdidos de vista, bem como uma diversidade de fundamentações teóricas orientando as posições dos autores, o que faz muita diferença para tornar as discussões menos consensuais.

Entre os autores que se aventuraram no terreno movediço dos assuntos relativos ao tráfico, merecem destaque os pensadores jesuítas, que, liderados por Luis de Molina SJ (1535-1600) - De iustitia et iure, tract. II, d. 3240 -, fizeram escola não só no tratamento do tema da escravidão negra em geral como no aspecto específico relativo às compras de escravos ${ }^{2}$. Embora tenham se destacado abordando o tema da escravidão indígena (principalmente no séc. XVI), também os dominicanos tiveram participação (bastante modesta, é verdade) no tratamento da escravidão negra no tocante ao tráfico, com destaque para Tomás de Mercado OP (1525-1575) - Summa de tratos y contratos, lib. II, cap. 20 -, que já bem no início das abordagens do tema da escravidão negra havia chamado a atenção para o problema da licitude das compras de africanos injustamente escravizados ${ }^{3}$.

Conquanto a força do pensamento jesuíta, na segunda metade do séc. XVII, através das obras e do ativismo de dois frades capuchinhos, vê-se o aparecimento de uma nova posição ante o tráfico, mais ousada que a dos autores que já haviam se ocupado do tema: uma posição de tolerância zero às injustiças nas compras de escravos e ao velado laxismo moral presente nas

2 Outros autores da escola jesuíta que merecem ser mencionados são: Fernão Rebelo SJ (1546-1608), Opus de obligationibus iustitiae, pars I, lib. I, q. 9-10; Tomás Sánchez SJ (1550-1610), Consilia seu opuscula moralia, lib. I, cap. 1, dub. 4; Alonso de Sandoval SJ (1576-1652), De instauranda Aethiopum salute; e Diego de Avendaño SJ (1594-1688), Thesaurus indicus, tit. IX, cap. 12 , §8.

${ }^{3}$ Apesar de Mercado ser o representante mais expressivo entre os dominicanos, antes dele podem ser encontrados três dominicanos abordando, en passant, o tema da escravidão negra: Francisco de Vitoria OP (1483/86-1546), em carta a um confrade seu; Bartolomé de Las Casas OP (ca.1484-1566), Historia de las Indias, t. I, cap. 17-27; t. III, cap. 102.119; e Domingo de Soto OP (1494-1560), De iustitia et iure, lib. IV, q. 2, a. 2 . 
discussões sobre a correção do tráfico e das consciências dos envolvidos nele. Assumida por Francisco José de Jaca OFMCap (1645-1689) - Resolución sobre la libertad de los negros y sus originariost $-\mathrm{e}$, principalmente, por Epifânio de Moirans OFMCap (1645-1689) - Servi liberi seu naturalis mancipiorum libertatis iusta defensio ${ }^{5}$ -, essa posição teve como marca a intransigência e, em nome do espírito evangélico e de tudo aquilo que se supunha ser justo, arvorava-se ser a única posição comprometida com a verdade e a justiça.

Conjuntamente pensada por Jaca e Moirans, mas sistematizada e desenvolvida em detalhes por este último, essa posição pretendeu exigir o fim imediato do tráfico e a adoção de medidas corretivas para reparar as injustiças cometidas pelos cristãos contra o povo africano. $O$ ponto fulcral que a embasava era o convencimento de que um modo de abordar seriamente o tráfico seria apartando-se do casuísmo reinante nas discussões da teologia moral da época, a fim de evitar inserir o tema das compras de escravos entre os muitos casos de consciência duvidosa que mobilizavam as discussões dos moralistas.

Embora Jaca e Moirans não discordassem do direito vigente (que previa o instituto da escravidão), e, portanto, como filhos de seu tempo e herdeiros do pensamento filosófico-teológico-jurídico medieval, aceitassem a instituição escravidão civil e os títulos de justa escravidão existentes, eles tinham discordâncias em relação ao casuísmo enquanto fórum de discussão do tráfico, e essas discordâncias foram propulsoras de seus libelos não só contra os vendedores, compradores e possuidores de escravos como também contra todos que consentiam com a manutenção do tráfico.

Por certo, a aceitação do direito vigente não levaria Jaca e Moirans a reprovarem a escravidão negra, exceto pela análise do modo como as escravizações ocorriam, o que seria válido, o que eles fizeram (como tantos outros), mas pouco eficaz para uma condenação enfática da mesma, i.e., "no todo" e para além de censuras a injustiças pontuais. No entanto, o afastamento em relação ao casuísmo seria capaz de levá-los a uma condenação enfática. E daí ser esse afastamento um ponto relevante de inflexão no tratamento da escravidão negra. Sem poderem condená-la com base no direito, eles a condenaram a partir do tráfico, expondo não só a má-fé por trás do mesmo como também, e acima de tudo, o modo como os envolvidos se achavam em situação delicada por se valerem de orientações morais laxas e de alegações

4 Para informações sobre a vida, obra e pensamento de Jaca, cf.: GARCÍA (1982, p.29-62); GONZÁLEZ (2002; 2007a, p.506-518); e SARANYANA (2005, p.303-307).

5 Para informações sobre a vida, obra e pensamento de Moirans, cf.: GARCÍA (1982, p.29-46.63-105); GONZÁLEZ (2004; 2005; 2007a, p.519-530; 2007b). 
pouco verossímeis no tocante a uma matéria tão grave como a morte civil, matéria por si exigente do máximo rigor.

E expor como ocorre essa condenação da escravidão negra condenação que não é exatamente moral (por não haver dúvida sobre a justiça da escravidão civil), mas pela moral - a partir do tráfico é o intento deste estudo, mediante a apresentação do discurso de Epifânio de Moirans sobre as compras de escravos ${ }^{6}$.

Para tanto, procedo inicialmente uma contextualização sobre as discussões e os sistemas da teologia moral quinhentista e seiscentista e explico como o tema do tráfico adentra em tais discussões. Após, abordo o pensamento antiescravista de Moirans. Nessa abordagem, exponho sua condenação da escravidão negra a partir do tráfico e explico que essa condenação decorre de seu rechaço a alegações, nascidas no interior das discussões da teologia moral, que funcionavam como salvaguarda das consciências dos envolvidos no tráfico, bem como autorização para a manutenção da compra e venda de escravos.

\section{O tráfico de escravos e as discussões da teologia moral}

O que estava em questão para os escolásticos quinhentistas e seiscentistas quando escreviam sobre o tráfico era dizer se as compras de escravos eram lícitas ou não, analisando-as a partir de vários ângulos e considerando suas múltiplas circunstâncias de ocorrência. Para exemplificar isso, basta mencionar algumas distinções feitas pelos autores: distinção entre as compras ocorrentes na África e fora da África (na América ou Europa); entre compradores traficantes (compradores intermediários) e compradores finais (amos); entre agentes (compradores ou vendedores) de má-fé e de boa-fé; distinção sobre existência ou não de má fama sobre a procedência da mercadoria; distinção sobre ser ou não possível o comprador ter ciência da procedência (lícita) da mercadoria, entre outras. Ou, para sumarizar: a distinção entre "primeira compra" e "segunda compra", onde aquela designava as compras realizadas na África por traficantes que (em tese) teriam condição de atestar a procedência dos escravos, enquanto esta (a segunda) designava as

\footnotetext{
${ }^{6}$ Embora pudesse ser relevante abordar Jaca e Moirans conjuntamente, limito-me aqui a tratar de Moirans. Essa escolha decorre de o tratado Servi Liberi ultrapassar a Resolución sobretudo em sistematicidade e exaustividade. Ademais, decorre de Moirans maturar e desenvolver em detalhes teses que Jaca só apresentara de modo embrionário. Não obstante isso, Jaca é um autor de lembrança obrigatória neste estudo. Apesar das diferenças formais entre a Resolución e o tratado Servi Liberi, Jaca e Moirans estão completamente alinhados no conteúdo ao tratarem da escravidão negra.
} 
compras fora da África realizadas por amos que (em tese) não teriam condição de atestar a procedência lícita do que compravam7.

É verdade que entre os autores que escreveram sobre o tráfico havia preocupação em mencionar o modo como os escravos eram tratados, bem como as condições subumanas e degradantes a que eram submetidos, principalmente durante o traslado para a América. Não obstante, ao tratarem do tráfico, o ponto forte de suas reflexões centrava-se na licitude das compras, posto que haviam se multiplicado escrúpulos em relação a elas devido à suspeição em torno da justiça das escravizações. Isso se verifica, e.g., nas cartas trocadas entre Vitoria e seu confrade Bernardino de Vique OP (fl. 1546) e entre Sandoval e seu confrade Luís Brandão SJ (fl. 1611), nas quais aparece de modo candente o questionamento sobre a correção do tráfico ${ }^{8}$.

E, por si, a licitude das compras era um problema de grande envergadura e importância, não só porque a partir dele se detecta a tolerância ou não dos autores ao tráfico, como também, e acima de tudo, porque tal problema se relacionava com o tema da consciência (moral) - conscientia $(\text { moralis })^{9}$-, tema em alta na época e que ganhara relevância em razão de a consciência, enquanto regra intrínseca e próxima da moralidade, ser vista como uma espécie de garantidora da correção do agente em casos duvidosos.

À sombra do Aquinate (Summa Theologiae I-II, q.19, a.5; Quodlibet III, q. 12, a. 2), a teologia moral professava que o pecado ocorria quando se agia contra a lei ou contra a consciência (Compendium II, cap. 1, punct. 3-5). Seguir a lei era uma evidente fonte de correção. No entanto, quando estar sob a lei não

\footnotetext{
7 Para detalhes sobre essas distinções e sobre os autores que as sustentavam, cf.: AÑOVEROS (2000, p.124-130); e ANDRÉS-GALLEGO e AÑOVEROS (2002, p.150-156).

${ }^{8} \mathrm{~A}$ carta de Vitoria pode ser encontrada no apêndice da tradução castelhana de suas relectiones teológicojurídicas realizada por A. Pirotto, bem como no apêndice da tradução inglesa das relectiones, realizada por A. Pagden e J. Lawrance - cf. na lista de referências: VITORIA (1975; 1991). Quanto à carta de Sandoval, ela é reproduzida pelo próprio autor em De instauranda, lib. I, cap. 17.

9 Segundo Tomás de Aquino OP (1225-1274), filósofo que embasa o pensamento da Escolástica Barroca, o nome conscientia significa a aplicação da ciência a algo e a consciência (em sentido genérico) se define como $o$ ato (actus ao invés de potentia ou habitus) de aplicar um hábito ou um conhecimento a algum ato particular. Essa aplicação ocorre de dois modos: considerando se o ato é ou foi realizado - e.g.: quando alguém diz que tem consciência porque sabe se algo aconteceu ou não; ou considerando se 0 ato é ou foi lícito ou ilícito - quando a aplicação da ciência ocorre dirigindo um ato (e.g.: alguém diz que a consciência 0 induz ou obriga a fazer algo) ou avaliando a correção de um ato (e.g.: alguém diz que a consciência o acusa ou o desculpa pelo que fez) - cf. De veritate, q. 17, a. 1, co.; Summa Theologiae I, q. 79, a. 13, co.; In II Sententiarum, dist. 24, q. 2, a. 4, co. A consciência propriamente moral é respectiva ao segundo modo e é definida, no tratado sobre os atos humanos, como um certo dictamen rationis, que preceitua o que deve ser feito (Summa Theologiae la-llae, q. 19, a. 5, co.). Durante a Escolástica Barroca, é essencialmente esse sentido (prático) que predomina, cf., e.g.: Bartolomé de Medina OP (1527-1580), Expositio in la-llae, q. 19, a. 6; Francisco Suárez SJ (1548-1617), De bonitate et malitia, d. 12, sect. 1, n. 8; e Antonio de San José OCD (1716-1794), Compendium Salmanticense, tract. II, cap. 1, punct. 1.
} 
era certo ou quando a lei em si era dúbia, cabia maximamente à consciência garantir a correção. E era justamente quando se agigantava o papel e a responsabilidade da consciência que começavam as dificuldades, pois, sem a referência explícita do preceito estabelecendo o devido a ser feito, a consciência podia tornar-se duvidosa (conscientia dubia). E eis o ponto nodal de muitos debates da teologia moral e de parte substantiva do tratamento do tema do tráfico: a dúvida (dubium), o estado da consciência no qual não há assentimento ou dissenso, mas permanência na ambiguidade.

À teologia moral, a dúvida era um problema por expor o agente ao pecado (Quodlibet VIII, q. 6, a. 3; Compendium II, cap. 3, punct. 2). Evidenciando isso, Vitoria recomendava o aconselhamento aos sábios nos casos duvidosos e advertia que, mesmo acertando o resultado da ação, pecaria quem agisse com dúvida e quem não consultasse ou seguisse os sábios (De indis, pars I, incipit, n. 1-3). Logo, mais do que acertar, era imperativo vencer a dúvida, pois a superação dessa seria a solução para o problema da exposição ao pecado. Essa solução, todavia, foi tão ou mais problemática do que o problema em si da dúvida, pois se mostrou difícil e controverso estabelecer o modo pelo qual se poderia converter a consciência duvidosa (conscientia dubia) em certa (conscientia certa $)^{10}$.

Propugnando soluções para a superação da dúvida, surgiram os chamados sistemas morais, alguns enfatizando a ordem objetiva (acercamento à lei), outros, a ordem subjetiva (abertura à liberdade). É desnecessário aqui mencionar todos, mas alguns, como o tuciorismo, o laxismo, o probabilismo e

\footnotetext{
10 Essa distinção é de ordem subjetiva e refere-se ao modo como o agente assente e/ou adere a algo. Enquanto a consciência certa dita com certeza, e sem receio, que algo seja feito ou evitado, a duvidosa permanece dividida e não assente verdadeiramente. Em linha com esse estado de hesitação, também podem ser mencionadas a consciência provável (conscientia probabilis) - que, baseando-se numa opinião, assente a uma parte julgando-a lícita, mas com algum receio quanto à outra parte - e a escrupulosa (conscientia scrupulosa) - que adere a uma parte com receio de que erra ao fazê-lo. Essas distinções não são respectivas ao acerto ou erro. A distinção quanto a esse aspecto se refere ao objeto (não à performance do agente). No tocante ao objeto, a consciência se divide conforme a concordância ou não de seu ditame com a lei. Se concorda com essa, ditando como bom o que é bom ou como mau o que é mau, a consciência é reta ou verdadeira (conscientia recta/vera). Se, porém, discorda da lei, ditando como bom o que é mau ou como mau o que é bom, a consciência é errônea ou falsa (conscientia erronea/falsa). Essa modalidade, por sua vez, subdivide-se em invencivel (conscientia erronea invincibilis) e vencivel (conscientia erronea vincibilis), de acordo com a presença ou não de ignorância invencivel (ignorantia invincibilis) prejudicando 0 julgamento. Outras distinções quanto à consciência se referem ao tempo e à obrigação. Quanto ao tempo, a consciência pode ser antecedente (conscientia antecedens) ou consequente (conscientia consequens). Quanto à obrigação, ela pode ser preceptiva (conscientia praecipiens), consultiva (conscientia consulens) ou permissiva (conscientia permittens) - cf.: Compendium II, cap. 1-3; DONOSO (1855, t. 1, p. 402-410); KOCH e PREUSS (1925, v. 1, p. 182-202).
} 
probabiliorismo, são importantes para a compreensão tanto do contexto geral da teologia moral dos sécs. XVI-XVII ${ }^{11}$ quanto da matéria deste estudo.

O tuciorismo preceituava a máxima proximidade à lei em vez de abertura à liberdade, exceto se fosse certo (ou, ao menos, probabilíssimo) que não houvesse lei obrigante (ASTRAIN, 1920, t. 6, p. 129; ARAMINI, 2010, p. 93s). Propugnava que se devia seguir o "mais seguro" (tutior), fundamentandose no seguinte princípio reflexo12: "nas situações de dúvida, deve-se escolher a parte mais segura" (in dubiis tutior pars est eligenda) ${ }^{13}$. A opção pela tutior pars seria a escolha pelo acercamento a uma lei e teria o condão de eliminar ou minimizar o risco do pecado, e daí que segui-la fosse uma estratégia interessante para a produção de certeza capaz de justificar o indivíduo a passar à ação. Em Medina, que é normalmente visto como propositor do probabilismo, encontram-se exemplos de aplicação de tal princípio e em todos a detecção da tutior pars é estabelecida pela exposição ou não do curso de ação ao pecado, posto que tal princípio é entendido como uma espécie de "regra magistral" para orientar a ação, conquanto tenha limitações de aplicação em alguns casos (In Ia-IIae, q. 19, a. 6, p. 305).

$\mathrm{Na}$ mesma linha do tuciorismo, pela ênfase que também dava à ordem objetiva, mas o flexibilizando um pouco, o probabiliorismo preceituava que se devia seguir a opção em favor da lei, exceto se a opção em favor da liberdade ou autodeterminação do agente fosse "mais provável", probabilior (ASTRAIN, 1920, t. 6, p. 129; ARAMINI, 2010, p. 93s).

Opondo-se à ênfase ao seguimento da lei e realçando a subjetividade da consciência, probabilismo e laxismo propugnavam substancial latitude à escolha moral, pois viam nos casos duvidosos uma grande margem de atuação para a consciência.

\footnotetext{
${ }^{11}$ Não pretendo ser exaustivo na abordagem dos sistemas morais. Por isso, só menciono quatro. Registro, porém, que o tuciorismo pode ser dividido em absoluto e mitigado, e que, além do probabilismo e probabiliorismo, há também o equiprobabilismo. Para detalhes sobre os sistemas morais, suas denominações, características e distinções, cf., e.g.: ASTRAIN (1920, t. 6, p. 128-132); SARANYANA e GRAU (2005, v. 2/1, p. 185-197); ARAMINI (2010, p. 93-96).

12 Um princípio reflexo é um axioma que se aplica como norma em casos cuja solução é dificultada pela dúvida, ou, ainda, é uma fórmula que indica um critério de ação (O'REILLY, 2006, p. 29; ARAMINI, 2010, p. 93).

${ }^{13}$ Além de referido pelo Aquinate (In IV Sententiarum, dist. 27, q. 2, a. 3, arg. 2), tal princípio, segundo Deman (1936, col. 421-423), fundamentava-se em algumas regras do Corpus iuris canonici (Decretales Gregorii IX, lib. V, tit. 12, cap. 12; tit. 27, cap. 5). Sobre o texto original em latim que apresento após a citação no vernáculo, procederei dessa forma ao longo deste estudo sempre que 0 texto latino for breve $e$ relevante para o que estiver sendo tratado. Isso vale como regra para qualquer autor, incluindo Moirans. Adoto esse procedimento com vistas a evitar que este estudo resulte demasiado extenso. Quanto às traduções que apresento, todas são de minha responsabilidade.
} 
Amparando-se sobretudo no princípio reflexo "lei dúbia não obriga" (lex dubia non obligat) - de paternidade geralmente atribuída à Suárez (De bonitate et malitia, d. 12 , sect. 6, n. 8) -, o probabilismo entendia que a restrição quanto à essa margem de atuação concernia à probabilidade da opinião no tocante à matéria sobre a qual havia dúvida, i.e.: (concernia) à capacidade de a opinião ser provada - achando-se sustentada por argumentos excelentes, homens sábios e sendo conforme a reta razão (MEDINA, In Ia-IIae, q. 19, a. 6). Havendo opinião provável, poder-se-ia segui-la. Só seria vedado seguir uma opinião improvável. Destarte, todos os cursos de ação fundamentados em opiniões prováveis seriam legítimos de serem seguidos, mesmo que, concorrentemente, existissem cursos de ação em favor do cumprimento da lei embasados em opiniões mais prováveis ${ }^{14}$.

Não vem ao caso entrar nas minudências do probabilismo, mas é importante mencionar que sua paternidade é geralmente atribuída a Medina, autor que apresenta a fórmula, que se tornou pedra angular do probabilismo, para responder a controvérsia sobre a obrigatoriedade (ou não) de seguir a opinião mais provável, abandonando-se uma apenas provável, a saber: "se uma opinião é provável, é lícito segui-la, mesmo que contra uma opinião mais provável" (In Ia-IIae, q. 19, a. 6, p. 309). Fundamentalmente, a razão de ser de tal formulação repousava no entendimento de que a correção do seguimento do provável no campo do teórico podia ser transposta ao campo do prático: "uma vez que no especulativo a opinião provável é aquela que podemos seguir sem risco de erro e engano, segue-se que no prático a opinião provável é aquela que podemos seguir sem risco de pecar" (In Ia-IIae, q. 19, a. 6, p. 309). Destarte, independentemente de seu grau de probabilidade, já que mesmo uma opinião muito provável não chega a ser certeza, bastaria que uma opinião fosse capaz de ser provada para poder ser seguida no especulativo ou no prático.

No tocante ao laxismo, a margem de atuação da consciência era mais ampla em razão de esse sistema ser a antítese do tuciorismo. Em vez de preceituar o seguimento da lei exceto se houvesse certeza de inexistência de lei obrigante, o laxismo preceituava o seguimento da liberdade exceto se houvesse certeza da existência de uma lei ou se houvesse ao menos uma probabilidade, mesmo que tênue ou pequena, em favor da autodeterminação do agente (ASTRAIN, 1920, t. 6, p. 129s; ARAMINI, 2010, p. 94; MOLIEN; AMAN, 1926).

Rivalizando entre si, esses sistemas cumpriram o propósito de produzirem critérios que permitiram que o agente saísse da dúvida e não

14 Para detalhes sobre o probabilismo, cf., e.g.: CONCINA (1743); ASTRAIN (1920, t. 6, p. 119-372); DEMAN (1936); e SCHÜSSLER (2005). 
ficasse inerte frente às situações difíceis que caracterizam o campo da ação humana. É verdade que esses sistemas não proporcionavam ao agente o conhecimento de uma certeza teórica, mas todos foram importantes para o capacitarem a passar à ação à medida que o auxiliavam a obter certezas práticas.

E a existência de sistemas tão diversos em conjunto com a discussão sobre qual sistema seria mais apto a produzir certeza teve significativa repercussão nos debates sobre o tráfico de escravos africanos. A conexão entre esses fóruns de discussão aparentemente incomunicáveis residiu no fato de as compras de escravos se enquadrarem nos casos duvidosos de que se ocupava a teologia moral. Do mesmo modo que, na primeira metade do séc. XVI, a ocupação espanhola na América fora matéria de escrutínio da teologia moral, por parte de autores como Vitoria, em razão de ser matéria duvidosa - já que não era tão evidentemente injusta que não se pudesse dissentir de sua justiça nem tão evidentemente justa que não se pudesse duvidar de sua justiça (De indis I, n. 3) -, a partir da segunda metade do XVI e ao longo do XVII, o tráfico de escravos tornou-se alvo de investigação por também ser matéria que não comportava evidente justiça nem evidente injustiça. É claro que, por envolver controvérsias mais complexas, a ocupação espanhola (com as questões relativas aos ameríndios) recebeu mais atenção do que o tráfico. No entanto, a razão por que esses temas mobilizaram a atenção dos autores foi a mesma: tratavam-se de matérias em relação as quais se devia buscar esclarecimento para se formar uma boa consciência e para se orientar os envolvidos nelas a agirem com correção ${ }^{15}$.

Especificamente, o ponto nodal do problema da justiça da escravidão negra no tocante ao tráfico dizia respeito à dúvida acerca da procedência lícita do escravo, i.e., à dúvida, no ato da compra (ou mesmo posterior à ela), sobre se o escravo que estava sendo adquirido (ou fora adquirido) havia sido reduzido à escravidão com justo título, uma vez que era ampla a má fama em torno das escravizações na África, pois, para mencionar apenas algumas situações, era público e notório que eram injustas as guerras a partir das quais os africanos eram feitos escravos, bem como as penas de escravidão por delito $^{16}$.

150 próprio Molina apontava o paralelismo entre as duas matérias (a da ocupação espanhola e a do tráfico) e propugnava a necessidade de o tráfico ser investigada pelos doutores (De iustitia II, d. 35, n. 1-2).

16 Sobretudo Mercado chamou a atenção para o problema tanto das injustiças por trás dos títulos de escravidão quanto das fraudes, violências e roubos por trás das escravizações sem qualquer título, ao ponto de estimar que metade dos escravos transportados não haviam sido reduzidos à escravidão com justiça (Summa II, cap. 20). 
Ora, se um africano era reduzido à escravidão injustamente (i.e.: em desacordo com os títulos de justa escravidão), tratava-se de um escravo ilegítimo. Logo, não devia ser comercializado. E como os responsáveis pelas escravizações não tinham compromisso em procedê-las com justiça, competia, pois, aos envolvidos no tráfico (vendedores e compradores) procederem com justiça em seus negócios. Competia aos vendedores venderem escravos legítimos e aos compradores exigirem os títulos de escravidão dos escravos que seriam adquiridos. Nesse caso, haveria um círculo virtuoso: vendedores preocupados em venderem uma mercadoria lícita e compradores preocupados em adquirirem uma mercadoria lícita. Esse círculo, contudo, nunca existiu. A má-fé por trás das escravizações contaminou o tráfico e o que restou foi um grande círculo vicioso.

Aos olhos da teologia moral, essa situação era preocupante porque a má-fé dos envolvidos e o círculo vicioso estabelecido consistiam em ocasião de pecado. Frente a isso, a solução para evitar cometer pecado e injustiça seria que os compradores se certificassem da licitude dos escravos que iriam adquirir, exigindo dos vendedores a apresentação dos títulos de escravidão. Agindo assim, os compradores eliminariam o risco de agirem com a dúvida prática entre comprar ou não comprar, posto que tal dúvida dependia da eliminação de uma dúvida anterior, viz:: a dúvida teórica sobre se o escravo fora escravizado com justiça ${ }^{17}$. E aqui reside um ponto complexo da matéria.

A eliminação da dúvida teórica sobre se o escravo era lícito se mostrava praticamente inviável não só para os compradores da segunda compra como também para os da primeira - que enfrentavam, conforme Molina, a resistência dos vendedores africanos em falar sobre a procedência dos escravos (De iustitia II, d. 34, n. 6). Apesar disso, os compradores não se deixavam deter e adquiriam escravos. E militando em favor das compras apareciam alegações que, mesmo num cenário de incertezas, desempenhavam o papel de justificá-las, funcionando como salvaguarda das consciências dos envolvidos no tráfico. Entre tais alegações, podem ser mencionadas: a da ignorância invencível; a da boa-fé; a da incomunicabilidade entre dúvida teórica e prática; e a da superação da dúvida mediante opiniões prováveis.

\footnotetext{
${ }^{17} \mathrm{~A}$ distinção entre as dúvidas teórica e prática diz respeito ao ordenamento ou não das mesmas à ação. $\mathrm{A}$ dúvida de $\mathrm{X}$ sobre se sua herdade é mesmo sua, após ter sido reclamada por $\mathrm{Y}$, é tão-só especulativa. Entretanto, a dúvida de $X$ sobre se deve ou não entregar a herdade a $Y$ trata-se de uma dúvida prática. Adicionalmente, estando esta última dirigida à ação, trata-se de uma dúvida sobre cometer ou não pecado cf.: SOTO (De ratione tegendi et detegendi secretum, pars III, q. 2; De dubio et opinione, n. 8); MEDINA (In la-llae, q. 19, a. 6); Compendium II, cap. 3, punct. 1; DONOSO (1855, t. 1, p. 404s). Ainda nesta seção, retomarei o tema da dúvida e mostrarei que a distinção em questão se constituiu numa espécie de alegação autorizadora da manutenção do tráfico.
} 
A ignorância invencível (ignorantia invincibilis) consiste na privação de conhecimento, que não é possível ser superada pelo esforço do agente moral, de algo devido (quanto a lei ou quanto ao fato), cuja causa não depende de modo algum do agente e da qual ele não é culpado por não estar em seu poder conhecer aquilo que ignora irremediavelmente. Ademais, trata-se de uma ignorância que é antecedente, o que reforça que seja desculpável, pois é ela mesma que causa o involuntário ${ }^{18}$.

No tocante ao tráfico, a ignorantia constava no argumento de que os envolvidos nas compras poderiam se encontrar invencivelmente privados do conhecimento necessário para bem agirem. Nesse caso, o erro de julgamento não seria voluntário e, logo, haveria uma consciência errônea (conscientia erronea), mas não uma vontade má, o que se considerava desculpável, apesar de se ter produzido um mal.

E por mais inverossímil que fosse a alegação de ignorância, não era impossível de ser feita. Molina, mesmo descrendo da pertinência dessa alegação por parte dos traficantes na África, ressalvava que os mesmos não estariam em estado de condenação se alguma ignorância invencível os escusasse e reconhecia que o eventual comprador ignorante ao qual sobreviesse dúvida sobre a licitude do título de escravidão poderia manter a posse do escravo enquanto não a dirimisse (De iustitia II, d. 35, n. 16.21). E a mesma ressalva era também feita por Salón (Commentariorum in disputationem de iustitia, q. 3, a. 1).

Quanto à boa-fé (bona fides), também esta desculpa uma consciência errônea, posto que, analogamente à ignorância invencível, decorre de um convencimento material ou objetivamente errôneo que isenta a consciência por envolver involuntariedade no tocante ao cometimento do que é objetivamente mau (Compendium XIX, cap. 1, punct. 6; DONOSO, 1859, t. 4, p. 419-422; DUBLANCHY, 1910). Apesar de envolver consciência errônea, o ato de boafé envolve consciência certa. O problema, portanto, não é a falta de certeza pois o agente assente com convicção de que não faz nada errado -, mas o erro objetivo.

Em relação ao tráfico, a alegação de boa-fé recaia basicamente sobre os compradores que mercavam fora da África e que, em tese, ao contrário dos compradores da primeira compra (que não só suspeitavam como sabiam das injustiças nas escravizações), poderiam formar o convencimento de que os

$18 \mathrm{O}$ conceito de ignorantia, quer em sentido genérico, quer quanto às suas várias espécies, é fartamente referido pelo Aquinate, cf., e.g.: Summa Theologiae la-llae, q. 6, a. 8; q. 19, a. 6, co.; q. 76, a. 1-4; In II Sententiarum, dist. 39, q. 1, a. 1, ad 4; d. 43, a. 1, ad 3; De Malo, q. 3, a. 8. Cf. também: Compendium I, cap. 2, punct. 4, §§4-5; Donoso (1855, t. 1, p. 56-58); Mangenot (1922). 
escravos eram legítimos. E tendo esse convencimento unido à convicção de que não faziam nada errado nem lesavam ninguém, esses compradores só poderiam mesmo ser considerados agentes de boa-fé, apesar de seus atos serem objetiva e materialmente maus.

Ademais, não só o indivíduo era desculpado pela boa-fé como o próprio ato praticado acabava sendo legitimado por ela, conquanto fosse lesivo para o africano injustamente escravizado. Molina é um dos autores que estabelece as bases desse entendimento sobre a boa-fé, sendo posteriormente seguido por outros. Para o mestre eborense, "todos aqueles que compraram de boa-fé escravos dos mercadores, ou os possuem através de outros que os começaram a possuir de boa-fé, podem licitamente reter seus escravos" (De iustitia II, d. 36, n. 1, p. 106).

É verdade que Molina ressalvou que a superveniência da dúvida deveria ensejar inquirição e, ao final, até mesmo a manumissão, caso a conclusão fosse pela injustiça da escravidão, podendo, até o deslinde da questão, o comprador manter a posse do escravo (De iustitia II, d. 36, n. 1). De qualquer forma, tal entendimento favorecia uma alegação que mais legitimava a compra que propriamente desculpava o comprador. Isso se torna patente na tese de que, em caso de suspeita, poder-se-ia adquirir escravos a partir do momento em que eles fossem possuídos de boa-fé por alguém, mas não enquanto se encontrassem sendo vendidos pelos traficantes:

Alguém que esteja persuadido de que os escravos, transportados da África, em
grande parte foram injustamente reduzidos à escravidão, pode licitamente
comprá-los, não enquanto possuídos pelos próprios traficantes que os
transportaram, mas após terem sido possuídos de boa-fé por outra pessoa.
Subsequentemente, deverá fazer uma investigação moral para saber se o escravo
comprado foi legitimamente reduzido à escravidão no princípio, ou se começou
a ser possuído sem título [...]. Se nada for descoberto a respeito (como
geralmente sucede) ou se, feita a investigação moral, não se descobrir nada
certo, a nenhuma restituição terá direito o escravo e poder-se-á licitamente
possuí-lo (De iustitia II, d. 36, n. 3 p. 107).

A ressalva sobre a necessidade de investigação tem pouco peso para o que é realmente sustentado e não passa de um cuidado da parte de Molina. A tese forte é que a boa-fé teria o condão de legitimar a compra, e não apenas desculpar uma consciência errônea.

A boa-fé também foi alegada de modo curioso por Sánchez, que, segundo Avendaño (Thesaurus IX, cap. 12, \$8, n. 180), foi o autor que mais magistralmente tratou das questões sobre o tráfico após Molina. Sánchez, num raciocínio semelhante ao de Molina, pensa uma espécie de transmissão de boafé do vendedor para o comprador. Suponha-se que X é um comprador de máfé ou que tem dúvida e Y um vendedor de boa-fé. Conforme Sánchez, se X 
compra um escravo ilegítimo de $\mathrm{Y}$, em razão de $\mathrm{X}$ suceder a $\mathrm{Y}$ no direito, $\mathrm{X}$ não está obrigado a manumitir o escravo (Consilia I, cap. 1, dub. 4, n. 15).

É desnecessário mencionar as críticas havidas a essa posição, mas se deve notar que a alegação da boa-fé teve peso nas discussões sobre o tráfico, desempenhando, adicionalmente ao papel de desculpar uma consciência errônea, também o papel de legitimar compras de africanos injustamente escravizados e de convertê-los, com base do título de compra e na consciência do comprador (e não mais com base nos títulos de escravidão), em "propriedade legítima" ou em "escravo legítimo" - embora esta expressão mereça ser preterida por ser pouco inteligível admitir que o título de compra fosse capaz de converter em justa uma escravização que originalmente ocorreu contra o direito.

Quanto à incomunicabilidade entre dúvida teórica e prática, tal alegação não se referia à consciência errônea merecedora de desculpa, mas à consciência que, apesar da dúvida, supera-a, esclarecendo-se acerca da natureza da mesma, e torna-se certa (conscientia certa). Por óbvio, sua conexão com o tema da consciência concerne ao problema da ação em circunstância de dúvida e, especificamente, a se a dúvida teórica representa impedimento à ação. Quanto ao entendimento da matéria por parte dos escolásticos dos sécs. XVIXVII, o mesmo não chegava a ser matéria de disputa. Pelo contrário, havia inclusive consenso sobre vários aspectos: entendia-se que as dúvidas provenientes dos intelectos teórico e prático eram de naturezas diferentes; que a dúvida de natureza teórica não teria o condão de produzir dúvida prática; que o impeditivo para agir com consciência certa era a dúvida prática (não a teórica); e, por conseguinte, entendia-se que alguém poderia agir com consciência certa apesar de ter dúvidas teóricas e, também, apesar de essas dúvidas terem uma conexão tal com a ação ao ponto de, em sendo sanadas, tornarem-se decisivas para o estabelecimento de novos cursos de ação (diversos dos até então cumpridos quando a dúvida se mantinha insolúvel).

Um lugar recorrente de abordagem dessa matéria era onde se tratava da guerra justa, precisamente quando se indagava a participação dos súditos na deliberação das causas da guerra. O ponto problemático era se a dúvida de um súdito sobre a justiça da guerra o autorizaria a recusar-se a lutar e, logo, a desobedecer uma ordem do príncipe, com vistas a evitar agir com dúvida e expor-se ao pecado. O ponto, contudo, tal como apreciado por autores como Vitoria (De iure belli, n. 25.31), Molina (De iustitia II, d. 113, n. 5-6) e Suárez (De charitate, d. 13 , sect. 6, n. 8-12), para mencionar apenas alguns, era apenas aparentemente problemático e facilmente deslindado através da distinção entre dúvida teórica e dúvida prática, sendo o critério para isso o direcionamento ou não da dúvida à ação. Se alguém duvida que a guerra em que deve lutar é justa, 
não tem dúvida dirigida à ação. Tem apenas uma dúvida teórica (sobre a justiça da causa). Disso, porém, não se segue que possa vir a ter dúvidas dirigidas à ação (sobre lutar ou não), pois, no tocante ao prático, o curso de ação a ser levado a cabo é claro: o súdito deve obedecer ao mandado do príncipe, não só por este ter autoridade para ordenar como também por ser o legítimo responsável por examinar o tema da guerra. E isso era sustentado sobretudo a partir da autoridade de Agostinho (354-430), que afirmara que um justo, mesmo sob ordens de um rei sacrílego, poderia retamente lutar se fosse certo que a ordem não contradissesse um preceito de Deus ou se não fosse certo (e, logo, apenas duvidoso) que ela o contradissesse (Contra Faustum, lib. XXII, cap. 75; cf. Decretum Gratiani, pars I, causa 23, q. 1, can. 4).

Adicionalmente, a incomunicabilidade entre as dúvidas teórica e prática decorre do fator competência. Além de serem de naturezas distintas, essas dúvidas competem a diferentes pessoas dirimi-las: a teórica, ao príncipe; a prática, ao súdito. Embora deva recusar-se a lutar caso tenha certeza da injustiça da guerra, ao súdito não compete ocupar-se das causas da guerra. Compete-lhe ocupar-se das matérias que lhe dizem respeito, e não sendo a guerra uma delas, deve combater sem questionar e podendo estar seguro de que age bem ao fazê-lo, pelo menos até o momento em que lhe conste, de modo cristalino, a injustiça da guerra.

$\mathrm{Na}$ mesma esteira, entendendo que a dúvida teórica não concernia à ação bic et nunc, Soto (De ratione III, q. 2; De dubio, n. 8) e Medina (In Ia-IIae, q. 19 , a. 6) propugnaram a mesma incomunicabilidade entre as dúvidas teórica e prática e asseveraram que não pecaria quem agisse com dúvida teórica. $\mathrm{O}$ cônjuge com dúvida sobre a legitimidade de seu matrimônio não deve negar o débito conjugal. Mesmo com dúvida teórica, deve fazer o devido. $\mathrm{E}$ ao fazê-lo, não peca, mesmo que o matrimônio seja ilegítimo (cf. O’REILLY, 2006, p. 40s.77s). Destarte, em que pese a dúvida teórica, a consciência moral permanece íntegra. No entanto, sobrevindo certeza especulativa e dependendo do teor dessa, o que antes era autorizado pode tornar-se vedado, e fazê-lo pode resultar em pecado, pois, a uma só vez, pode representar ação contra a lei e contra a consciência.

No tocante ao tráfico, o expediente ora em pauta podia ser visto sendo usado para autorizar os compradores de fora da África a adquirirem escravos sem escrúpulos ou dúvidas práticas (sobre passar ou não à ação) em razão de a dúvida sobre a legitimidade da escravidão e a justiça do tráfico (dúvida) de natureza teórica - ser, na verdade, de responsabilidade de outrem saná-la: autoridades competentes, não só reais como também eclesiásticas (viz:: o rei de Portugal, mas também bispos, priores e confessores), e, secundariamente, os próprios compradores na África - não por sua autoridade, 
mas por sua competência para procederem investigações frutiferas (pelo menos em tese). E, de fato, há aqui um paralelismo com o caso do súdito com dúvida sobre a justiça da guerra. A dúvida teórica deve ser sanada em ambos os casos, mas não pelo súdito (soldado ou comprador), posto que a matéria não é reputada como de sua responsabilidade (ou como maximamente de sua responsabilidade).

Efetivamente, entre os autores que escreveram sobre o tráfico, não se encontra menção explícita à incomunicabilidade entre dúvida teórica e prática, contudo se observa a presença ou da tese de transferência de responsabilidade para as autoridades competentes ou da tese de avaliação da justiça do tráfico a partir do comportamento das autoridades frente ao mesmo.

Vitoria, em sua carta a Bernardino de Vique, não se limitou a dizer que a fraude das escravizações comprometia a justiça do tráfico. Acrescentou que não acreditava que tais fraudes fossem comuns, tampouco que o Rei de Portugal seria capaz de permiti-las, e, referindo-se aos escravos provenientes das guerras entre os próprios africanos, negou que os portugueses tivessem obrigação de averiguar a justiça das mesmas e apontou que não havia razão para escrúpulos por parte dos compradores de fora da África. Ademais, disse que compraria com tranquilidade alguém que lhe fosse apresentado como escravo (El tráfico de esclavos, in VITORIA, 1975) ${ }^{19}$.

$O$ ponto do mestre salmantino era que não competia aos compradores de fora da África escrutinar a licitude dos escravos. A esses compradores competia comprar, sem ficarem levantando questionamentos. $\mathrm{E}$ daí Vitoria abrir a carta dizendo o seguinte: "Acredite Vossa Reverendíssima que a quem for examinar as negociações dos portugueses não faltarão achaques por que parar. O remédio geral é que os envolvidos nas negociações não se detenham em perguntas e respostas, mas que fechem os olhos e sigam em frente" (El tráfico de esclavos, in VITORIA, 1975, p. 22).

Não é impossível que essa postura permissiva decorra do que Pagden (1986, p. 33) sugeriu ser uma espécie de legalismo por parte dos espanhóis, posto que, não provindo os escravos de regiões de onde a Coroa Espanhola tinha compromissos políticos, não haveria razão para assumir a responsabilidade pela averiguação da procedência das mercadorias que circulavam em seus domínios. No entanto, tratando-se de Vitoria, talvez seja mais provável que tal permissividade decorra menos de um legalismo e mais de um convencimento teórico e fundamentado de que a consciência dos

19 Para detalhes sobre essa carta, cf., e.g.: HÖFFNER (1957, p. 461s); ANDRÉS-GALLEGO e AÑOVEROS (2002, p. 24s.141-143.151). 
compradores permaneceria intacta apesar dos graves problemas atinentes às escravizações ilícitas.

Escrevendo num período em que o tráfico estava mais consolidado e infamado, Molina não desresponsabilizou o amo em dúvida de esclarecer-se sobre a licitude de seus escravos, contudo, ao estabelecer que os compradores de fora da África poderiam ter presumida boa-fé, remeteu a responsabilidade pela averiguação da licitude dos escravos às autoridades. Em seu parecer, não competia aos súditos indagarem se as mercadorias vendidas no reino (no caso: os escravos) eram legítimas, já que era atribuição do príncipe e seus ministros reais fazê-lo (De iustitia II, d. 36, n.1). E essa mesma posição era compartilhada por Rebello (Opus de obligationibus I, lib. I, q.10, sect.1, n. 4).

Adicionalmente, mencione-se que Molina pensava que a matéria inteira relativa ao tráfico merecia um escrutínio detido por parte da autoridade real competente (Felipe II), escrutínio que deveria ser análogo ao solicitado por Carlos V no tocante ao tema dos aborígenes americanos (De iustitia II, d. 35, n. 1-2). Destarte, não só a licitude dos escravos que circulavam no reino como também a justiça do tráfico como um todo (i.e.: o exame de consciência sobre o tráfico) deveriam ser investigadas pelas autoridades, não pelos súditos, presumidos serem compradores de boa-fé.

Ademais, também Avendaño, que parecera discordar de Molina quanto à responsabilidade da autoridade real pela circulação de escravos, viu o príncipe como o responsável por investigar a justiça do tráfico e, de modo mais amplo, como o detentor do poder de efetivamente permiti-lo, de modo que as compras estariam autorizadas mais por ele ter competência para permitir do que responsabilidade por investigar. E competiria ao príncipe permiti-lo ou por não lhe constar manifesta injustiça ou, constando essa, por haver razões urgentes para isso, como evitar males maiores (Thesaurus IX, cap.12, §8, n.194.204).

E em razão dessa tese de desresponsabilização dos súditos, percebese um sensível movimento de autorização do tráfico. Ora, se o tráfico estava a ocorrer sem vedação legal das autoridades reais e sem censura moral das autoridades eclesiásticas - que não demonstravam escrúpulos ante o mesmo e que reconheciam o direito dos amos ao excomungarem os ladrões de escravos $^{20}$-, então o mesmo estava autorizado aos súditos compradores de fora da África. Essencialmente, tal movimento segue a linha de transferência de responsabilidade do soldado para a autoridade real. Destarte, exceto havendo certeza da injustiça da causa da guerra e da ilicitude dos escravos

${ }^{20}$ Cf., e.g., o que relatam Molina e Avendaño sobre o modo como procediam tais autoridades no tocante aos envolvidos no tráfico: De iustitia II, d. 34, n. 6.14; d. 35, n. 2; Thesaurus IX, cap. 12, §8, n. 204. 
comercializados, um súdito estaria autorizado a combater e a comprar escravos, mesmo com dúvida teórica, e ao fazê-lo não pecaria, mesmo que, do ponto de vista objetivo, fossem injustas a causa da guerra e a causa da escravização.

Finalmente, quanto à alegação de superação da dúvida mediante opiniões prováveis, conquanto pareça concorrente com a última alegação mencionanda, efetivamente não o é. A alegação das opiniões prováveis não supõe a incomunicabilidade entre as dúvidas, entende que é preciso superar a dúvida teórica para se passar à ação, mas propugna a prescindibilidade de certeza teórica à medida que reconhece a suficiência das opiniões prováveis para dirimirem a dúvida teórica e autorizarem a passagem à ação. Tal alegação se referia a investigações que se faziam devidas basicamente em três situações: previamente à compra; posteriormente à compra devido presença de dúvida durante a compra; posteriormente à compra devido à superveniência de dúvida.

Referindo à primeira situação, Avendaño, em seu Thesaurus indicus, propugnou não ser necessário constar de modo certo a licitude do título, por entender que a consciência estaria salvaguardada fundando-se numa "sentença provável” (IX, cap.12, $\$ 8$, n.191, p.326s). E uma mesma reverência ao seguimento do provável reaparece no Thesaurus quando Avendaño, finalizando sua apreciação do tráfico, após expor quatro proposições condenando-o, apresenta uma última na qual admite que o mesmo poderia justificar-se de "alguma forma" (IX, cap. 12, $\$ 8$, n.204, p.330). Nesse empenho, o autor desloca sua atenção da questão da licitude do título de escravidão (enquanto elemento autorizador ou não das compras) e passa a considerar a possibilidade de manutenção do tráfico a partir de outras razões, estranhas ao tema da licitude ou não do título de escravidão, mas nem por isso incapazes de produzirem a probabilidade que salvaguarda a consciência do teólogo que avalia a justiça da matéria ou dos muitos envolvidos no tráfico, que poderiam, mesmo constando alguma opinião favorável à ilicitude do título ou à existência de lei vedando a ação, seguir uma opinião contrária a isso.

$\mathrm{Na}$ mesma esteira, mas referindo-se à segunda situação, Sánchez apontava que quem comprasse um escravo com dúvida pecaria mortalmente e deveria manumiti-lo, exceto se pudesse dirimir a dúvida com "razões mais prováveis" (Consilia I, cap. 1, dub. 4, n. 15, p. 6).

Destarte, o recurso às opiniões prováveis mostrava-se sugestivo para dirimir dúvidas, pois, ainda que fosse pouco provável que algum escravo tivesse sido reduzido à escravidão com justiça, de modo algum seria errado seguir uma opinião dessas devido a seu caráter ainda assim provável. Suplementarmente, seguir o provável se mostrava sugestivo por significar 
seguir um caminho menos perigoso que o laxismo e mais interessante que o tuciorismo, pois, embora este sistema respondesse bem à exigência de uma moralidade séria, ele não tinha tanta eficácia para tirar o agente da inércia em razão de o tráfico ter se tornado um lugar oportuno ao pecado.

Mas se ignorância invencível e boa-fé podiam ser alegadas, se a dúvida teórica não era capaz de ensejar dúvida prática e se o caminho do provável era legítimo, então os compradores poderiam passar a ação. E, de fato, não só poderiam como efetivamente passaram. O ponto problemático disso, no entanto, era que, examinando-se com atenção a matéria, nada levava a crer que tais alegações pudessem realmente autorizar os envolvidos no tráfico a passarem à ação. Embora fossem legítimas, quando aplicadas ao caso do tráfico, tais alegações tornavam-se subterfúgios. Isso, porém, só pode ser afirmado levando-se em conta o pensamento antiescravista de Epifânio de Moirans, pois nele residem teses contundentes de que tais alegações eram inadequadas e de que levar o tráfico para ser discutido no âmbito do casuísmo significava, ao final, consentir com sua manutenção.

\section{Discurso de Moirans contra o tráfico de escravos africanos}

Em Servi Liberi, a condenação que Epifânio de Moirans realiza à escravidão negra ocorre tanto no exame dos títulos de escravidão quanto na análise do tráfico de escravos. No entanto, é no tratamento do tráfico que aparece a condenação mais enfática da escravidão, pois Moirans apresenta uma condenação do tráfico "no todo". Por si, isso é notável, uma vez que Moirans aceita a licitude da escravidão civil, e resulta incomum que um autor que aceite a licitude dessa escravidão profira mais do que censuras pontuais às injustiças ocorrentes. Não obstante, Moirans procede exatamente uma condenação "no todo" do tráfico, não tendo divergência com a justiça da instituição escravidão civil.

Para tanto, empenha-se em evidenciar os graves problemas morais por trás da escravidão negra, como forma de subsidiar uma condenação dessa pela moral, mostrando a falência de argumentos baseados em alegações da teologia moral que funcionavam como salvaguarda das consciências dos envolvidos nas compras e vendas de escravos e, logo, como autorizadores da manutenção do tráfico.

Antes, porém, de entrar nos detalhes desse pensamento antiescravista, considerando que Moirans não é um autor muito conhecido, 
apresento uma nota informativa sobre a obra Servi Liber ${ }^{21}$. Escrita entre 1681 e 1682 e datada de 1682, quando Moirans está preso em Havana, essa obra é concebida tendo como base a Resolución de Jaca. Redigida em latim, contém 14 capítulos e 137 parágrafos, e consiste num tratado de filosofia, direito e teologia, com ênfase na moral. Quanto à estrutura, pode ser dividida em cinco partes: 1. Conclusões - estabelecidas na abertura da obra, sendo três delas (as três primeiras e mais importantes) referentes ao tráfico e à necessidade de reparação das injustiças cometidas contra os africanos; 2. Prólogo e capítulo introdutório (cap. I) - que explicam o que dá ocasião e motivo à obra e informam, mediante relatos de fatos presenciados pelo autor, a crueza da realidade da escravidão; 3. Análise dos títulos de justa escravidão (II-V); 4. Disputa com autores adversários (VI-XI) - sobretudo com autores jesuítas; 5. Discurso sobre a restituição (XII-XIV). Quanto ao argumento da obra, o mesmo é claro e fica visível a partir de sua estrutura: vencidas as considerações preliminares, Moirans analisa os títulos de escravidão a fim de provar que os africanos eram escravizados contra o direito e, no que segue, em um trabalho dialético hercúleo, refuta as posições de autores que, mesmo reconhecendo a existência de injustiças nas escravizações e no tráfico, mostraram-se tolerantes à manutenção do tráfico; finalmente, Moirans conclui propondo a solução para o problema da escravidão negra: a restituição e a satisfação pelas injustiças cometidas contra o povo africano.

\subsection{Condenação irrestrita do tráfico de escravos devido à má-fé e falência das alegações de ignorância e boa-fé}

Em Servi Liberi, o discurso sobre o tráfico é central. Ele ocorre ao longo de toda a obra, conecta-se com distintos núcleos argumentativos da mesma e reflete a intenção de Moirans de proclamar um basta ao tráfico e exigir a correção das injustiças do mesmo. Não obstante, há dois lugares onde esse discurso desponta: (i) quando Moirans examina o direito e os títulos que legitimariam a escravização dos africanos - caps. II-V; e (ii) quando disputa com autores adversários - caps. VI-XI.

Apesar de o exame dos títulos de escravidão não ser por si um tema que se relaciona diretamente ao tráfico, tal exame é coordenado com o tema do tráfico em vista de produzir a condenação pretendida do mesmo, o que reflete a adoção de uma perspectiva metodológica de análise da escravidão negra distinta da seguida por outros autores, posto que o fatiamento ou não da

21 Doravante, menciono-a nas referências como SL. Trabalho aqui com a edição crítica de Miguel Anxo Pena González (cf. na lista de referências MOIRANS, 2007). Os parágrafos e páginas indicados, portanto, são sempre respectivos ao texto estabelecido por González. 
análise reflete na conclusão sobre a correção ou não do tráfico, já que, conforme notou González, analisar a compra distinguindo-a do ato de escravização permitia que se deslocasse a atenção das injustiças havidas nas escravizações para os problemas de consciência dos compradores (2007a, p. 500s). E daí que seja no exame dos títulos que Moirans prove três conclusões relativas à manutenção do tráfico e da posse de escravos já adquiridos:

Conclusão 1. "Ninguém pode comprar ou vender nenhum dos escravos de África, denominados comumente de negros" (Nemo potest emere aut vendere ullum ex mancipiis Africae, nigris communiter nuncupatis);

Conclusão 2. "Todos os que possuem alguns deles estão obrigados a manumiti-los, sob pena de condenação eterna" (Omnes qui possident quaedam ex illis tenentur manumittere, sub poena damnationis aeternae);

Conclusão 3. "Ao manumiti-los, os senhores devem pagá-los por seus serviços e indenizá-los" (Tenentur domini corum manumittendo restituere eis labores eorum et solvere pretium - SL, argumentum libri, p. 4, passim $^{22}$.

Nos caps. II-V, essas conclusões são provadas como consequência lógica de os africanos terem sido injustamente escravizados. Para Moirans, o ponto fundamental a ser considerado na análise da correção do tráfico não deveria ser maximamente a consciência dos compradores, mas as injustiças cometidas contra os africanos, dado que não raramente a boa-fé e a ignorância eram alegadas como justificadoras dos compradores e, logo, não era incomum ocorrer de um africano injustamente escravizado converter-se em escravo legítimo devido à eventual boa-fé ou ignorância havida nas compras.

Quanto ao segundo lugar mencionado (disputa com adversários), o tema do tráfico desponta no mesmo por Moirans estar empenhado em refutar as posições de autores que, mesmo reconhecendo a ocorrência de injustiças nas escravizações, mostravam-se tolerantes à manutenção do tráfico ao concederem a validade de alegações usadas para desculparem ou justificarem as consciências dos compradores.

${ }^{22}$ Ao todo, constam cinco conclusões, mas são as três primeiras as mais significativas para o discurso sobre 0 tráfico e para o desenvolvimento do tratado. As outras referem-se ao cuidado quanto à salvação (espiritual) dos africanos e a uma espécie de maldição contra aqueles que injuriaram o povo africano: "4. Os negros habitantes de lugares das Índias nos quais são tidos por escravos, estão obrigados, por direito divino natural, a deixar esses lugares e a buscar outros lugares nos quais se cuide de sua salvação eterna; 5 . Por causa da injúria contra os negros, trasladados de suas terras e exportados às Índias, os príncipes cristãos fugirão dessas terras e perdê-las-ão, os bispos e clérigos emigrarão delas e navegarão como fugitivos e os cristãos serão feitos prisioneiros e escravos" (SL, argumentum libri, p. 4). 
Antes de disputar, no entanto, Moirans empenha-se em provar as conclusões mencionadas. Ao fazê-lo, propugna sua perspectiva metodológica de análise, vinculando sem transigir a justificação dos títulos de escravidão às escravizações, reprova as alegações de ignorância e boa-fé e estabelece as bases de uma engenhosa refutação ao argumento da dúvida que favoreceria o possuidor de escravos, (argumento) que era recorrente na época, bastante usado nas discussões sobre o tráfico e cujo fundamento era o princípio reflexo "na dúvida, é melhor a condição do possuidor" (in dubio melior est conditio possidentis) ${ }^{23}$. E tudo isso ocorre no cap. II, que é porta de entrada para a argumentação substantiva do missionário e programático para o desenvolvimento do tratado Servi Liberi.

No cap. II, após dissertar sobre a liberdade natural do homem (n. 2526) e explicar que, apesar de o pecado ensejar a perda da liberdade, a pena da morte civil (escravidão) só é legítima havendo pecado ou crime e promulgação da mesma por autoridade pública (27-30), Moirans conclui que "os negros de África são feitos escravos contra o direito natural" (contra ius naturae fiunt servi nigri Africae - 31, p.42) - por não serem seus pecados o motivo das escravizações e por não terem autoridades públicas - e estabelece que agem contra o direito natural não só os que capturam e reduzem os negros à escravidão como também os compradores, vendedores e possuidores, pois "os negros têm direito natural à sua liberdade e estão em posse dela até que por seus pecados sejam dela privados por autoridade pública" (ius naturale habent ad suam libertatem nigri, et in possessione eius sunt, donec pro peccatis suis publica authoritate priventur illa - 31, p.44). Destarte, "a menos que esteja certo sobre a justa escravidão" (nisi certus de iusta servitute - 31, p.44) e "a menos que os títulos de justa escravidão sejam justificados e verificados" (nisi iustificatis et verificatis titulis

${ }^{23}$ Esse princípio deriva de uma regra do Corpus iuris canonici que ajudava a decidir casos duvidosos sobre a propriedade de bens: "Em igualdade de falta ou causa, é melhor a condição do possuidor" (In pari delicto vel causa potior est conditio possidentis - Liber VI Decretalium, lib. V, tit. 12, de regulis iuris, n. 65). De acordo com esse princípio, um possuidor de boa-fé de algo não poderia ser privado de tal posse enquanto a ilicitude da mesma não fosse suficientemente estabelecida (SCHÜSSLER, 2005, p. 98; BRETZKE, 2013, p. 139). Havendo equilibrio de razões de ambas as partes, deveria ser favorecida a parte que estivesse em posse do bem reclamado em razão de esta ter a seu favor dois direitos - um duvidoso sobre a propriedade, outro certo sobre a posse - contra apenas um direito - duvidoso sobre a propriedade - da parte não detentora da posse (Compendium II, cap. 3, punct. 3). Segundo Schüssler (2005, p. 98-100), no séc. XVI, contudo, além de aplicar-se ao escopo do direito de propriedade, tal princípio passou a ser aplicado a áreas mais amplas da conduta moral, sendo usado como uma espécie de regra de consciência. Além de encontrar-se aplicado a matérias relativas à guerra e, logo, à posse de países, tal princípio aplicava-se à posse de pessoas. Soto, e.g., usou-o para justificar a obediência do soldado às ordens do príncipe. Estando o soldado em posse do príncipe, não poderia a dúvida legitimar sua recusa em lutar, mas sim a obediência ao mandado do príncipe. Nessa mesma esteira de latitude interpretativa e com escopo de aplicação ampliado, tal princípio era requerido para sanar a dúvida superveniente dos amos, os quais, ao aplicá-lo, estando em posse de seus escravos, poderiam concluir pela licitude da manutenção de sua posse. 
iustae servitutis - 32, p.46), ninguém (nemo) pode comprá-los. E contra essa vedação resultaria pouco útil alegar que o tráfico se convertera em prática comum ou que nem todos os negros eram injustamente escravizados, por ser inadmissível que a corruptela do tráfico pudesse se sobrepor ao direito natural dos negros, bem como em razão de a alegação de que nem todos eram escravos ilícitos não servir como autorização para comprar, mas como alerta para não se passar à ação $(32, \mathrm{p} .44 \mathrm{~s})$.

Entretanto, o ponto nodal da argumentação está por vir. Até aqui Moirans argumentou apenas teoricamente e valendo-se da lógica e de seus conhecimentos de teologia, filosofia e direito. Dizer que ninguém pode comprar escravos a menos que conste de modo certo a justiça da escravidão não é suficiente para condenar o tráfico como Moirans pretende ("no todo"), mas apenas a compra e venda de africanos injustamente escravizados. $\mathrm{Na}$ verdade, um passo a mais deve ser dado para se passar da conclusão só possível com a ressalva nisi certus de iusta servitute para a conclusão que condena incondicionalmente o tráfico, dizendo que ninguém pode comprar ou vender escravos (conclusão 1).

O passo é, então, dado por meio de dois juízos empíricos. O primeiro é formulado recorrendo-se a Mercado (Summa II, cap. 20), que dissera que os traficantes na África só faziam perguntas genéricas sobre a procedência dos escravos, sem investigarem detidamente os títulos de escravidão dos mesmos. A partir disso, Moirans infere que "por nenhum contrato se justificam os títulos de escravidão [na África]" (Nullo tamen pacto iustificant titulus servitutis - 32, p. 46). O segundo juízo é formulado a partir do primeiro, mas ampliando sua abrangência (geográfica), com base no conhecimento do missionário sobre a realidade do tráfico: "comumente, os títulos de justa escravidão não são verificados ou justificados nem na América nem na África" (Non verificantur autem nec iustificantur tituli iustae servitutis, nec in America nec in Africa communiter 33, p. 46).

Frente a isso, tem-se a conclusão esperada de que ninguém (nemo) pode comprar ou vender escravos (conclusão 1), pois não se verifica de forma alguma na prática a ocorrência da ressalva que autorizaria as compras (nisi certus de iusta servitute), dado que, e efetivamente é isto o que Moirans quer dizer: ninguém verifica nada em lugar algum.

Mas, nesse caso, e juntando-se a isso a difundida má fama do tráfico, restava evidente que eram inadequadas quaisquer alegações de ignorância invencível ou de boa-fé, pois não ocorriam as condições necessárias para poderem estar desculpados os envolvidos no tráfico.

Adotando uma posição semelhante à de seu confrade Jaca (Resolución, pars I, n. 10-12), Moirans nega poder haver alguma ignorantia iuris ou facti em 
razão de ninguém poder desconhecer o que é de direito natural - como a liberdade, só passível de perda mediante delito - tampouco a situação das escravizações fraudulentas, fato público e notório, reportado não só por teólogos e doutores como pelos próprios traficantes e marujos (SL II, 33-34, p.48s; cf. VI, 69, p.100). E considerando sobretudo a impertinente alegação de ignorantia facti, a única ignorância possível seria, na melhor das hipóteses, a crassa (ignorantia crassa), pois o rumor das injustiças inviabilizava a possibilidade de invencibilidade e exigia a vigilância dos envolvidos - que deveriam apurar a legitimidade dos títulos (cf.: SL XII, 125, p.194; XIII, 126, p. 200). Nesse caso, se pudesse haver ignorância, só o poderia devido à negligência. Contudo, sendo a negligência o motivo da ignorância, não seria possível desculpa, pois a consciência seria vencivelmente errônea e, logo, punível.

$\mathrm{E}$ a mesma razão por que seria impertinente a alegação de ignorância aplica-se à de boa-fé. $\mathrm{O}$ rumor das injustiças não oportunizava situações de confiança. Pelo contrário, ensejava um cenário de absoluta desconfiança, o qual, sendo também um ambiente propício para o pecado, exigia a máxima vigilância dos envolvidos. Assim sendo, qualquer alegação de boa-fé equivalia a uma admissão de negligência e a uma confissão de pecado. O mais grave disso, porém, era que, frente a tal cenário (de desconfiança), a consciência errônea fiada não poderia ser considerada desculpável. E por tudo isso é que Moirans propugna exaustivamente ser impossível alegar boa-fé sem antes investigar os títulos de justa escravidão.

Destarte, tal como se encontrava disposto, o cenário das escravizações e do tráfico se incompatibilizava com a condescendência a negligências e com quaisquer alegações que repugnassem uma atitude vigilante. E daí que a ignorância invencível e a boa-fé sejam rechaçadas. Tal rechaço, contudo, não é por si o que de mais importante há no discurso de Moirans. O mais significativo é a admissão de tais alegações contanto que vinculadas à necessidade de investigação. Ao mesmo tempo em que isso torna sensato o discurso do autor, torna-o também corrosivo e o fortifica para condenar o tráfico. A razão disso é que tal vinculação lhe permite conectar as alegações de ignorância e boa-fé ao juízo empírico de que os títulos não eram verificados e, logo, condená-las absolutamente com base na verdade desse juízo. Ora, se, por um lado, só se pode alegar ignorância ou boa-fé contanto que se investigue, mas, por outro lado, ninguém investiga coisa alguma, então ninguém pode alegar ignorância ou boa-fé para desculpar-se, pois todos que o alegam agiram com consciência errônea vencível, merecem, por isso, ser punidos e se acham em estado de condenação enquanto mantêm consigo aquilo que adquiriram com má-fé, pois, não podendo confiar ou ignorar, agiram com pura má-fé. 
Não é novidade que Moirans tenha enfatizado o papel da investigação nas compras. Isso já havia sido feito por Mercado (Summa II, cap. 20). No entanto, é notável o trabalho do capuchinho de vincular o tema da investigação a tudo o que concernia ao tráfico com vistas a estabelecer a conclusão pelo fim do mesmo com base no juízo de que ninguém investigava coisa alguma em lugar algum. Mais do que conclusões teóricas, interessava-lhe estabelecer conclusões práticas, e daí que tudo o que diga sobre o tráfico refirase sempre ao juízo de que ninguém investigava, pedra angular de seu arrazoado.

Por tudo isso, pode-se dizer que o tráfico, conforme o parecer de Moirans, não passava de um negócio sujo e iníquo. No geral, todos os envolvidos agiam irresponsavelmente e desrespeitavam o direito natural dos africanos à liberdade. Logo, a solução para o problema do tráfico não poderia ser outra senão o seu fim, tal como enunciado na conclusão 1.

Não obstante, estabelecer a conclusão 1 ainda não é suficiente para Moirans. Essa conclusão diz apenas que as compras devem parar, mas não resolve integralmente o problema do tráfico, o qual, por sua vez, envolve não só a compra e venda de escravos como também as injustiças cometidas contra o povo africano e a necessidade de restituição e reparação por essas (i.e.: medidas corretivas). Ademais, a não abordagem do problema das injustiças poderia enfraquecer a conclusão 1 , posto que a não exigência da restituição da liberdade através da manumissão tornaria pouco inteligível a vedação expressa na conclusão 1, uma vez que africanos injustamente escravizados já comercializados poderiam ser retidos justamente por traficantes sem, contudo, poderem ser vendidos.

Destarte, para propor uma solução coerente para o problema do tráfico, Moirans dá um passo a mais em seu arrazoado e trabalha em vista de estabelecer conjuntamente as conclusões 2-3, ambas respectivas à adoção de medidas corretivas para sanar as injustiças havidas, através da manumissão, do pagamento pelos serviços prestados e do pagamento de indenizações ${ }^{24}$. Esse passo ocorre no exame dos títulos (mormente no cap. II) e na disputa com adversários (caps. VI-XI) e é dado através de um movimento argumentativo único que compreende dois instantes lógicos (não cronológicos) interdependentes: o do estabelecimento propriamente dito das conclusões e o

\footnotetext{
${ }^{24}$ As conclusões 2-3 referem-se ao discurso sobre a restituição, ocorrente nos caps. XII-XIV. Esse discurso é importante para a estrutura da obra, porém não chega a gozar de autonomia na mesma por depender do que é dito no cap. II, dado que só faz sentido falar em restituição mostrando-se a ilicitude da posse dos escravos.
} 
da refutação do recorrente argumento sobre a dúvida que favoreceria o possuidor (de escravos).

O estabelecimento das conclusões 2-3 não passa de uma consequência da conclusão 1 . Se não se pode comprar e vender escravos porque ninguém investiga e, logo, age com má-fé, então não se pode reter o que foi adquirido com má-fé e contra o direito natural. E daí Moirans dizer, antes de estabelecer as conclusões 2-3, que "das ações contra a lei natural feitas na captura de escravos na África decorre necessariamente que são contra a lei natural sua compra e venda na América, bem como, por conseguinte, sua posse [possessio]" (SL II, 33, p.46s).

Entrementes, mais importante que dizer que a posse contrariava a lei natural era responder a quem arguia que a posse de escravos já adquiridos poderia ser mantida enquanto não se obtivesse certeza (teórica) sobre a licitude do título de escravidão ou, inclusive, caso fosse infrutífero o inquérito da verdade, pois, tanto durante o inquérito quanto após um inquérito frustrado, os possuidores de escravos estariam justificados pelo princípio "na dúvida, é melhor a condição do possuidor" (doravante: princípio do possuidor).

Em vista de responder à alegação do princípio do possuidor, Moirans argumenta com argúcia para fechar a última porta de tolerância ao tráfico (deixada aberta por vários autores) e para, enfim, declarar o fim do mesmo e a obrigação de os cristãos repararem seus malfeitos. Para tanto, demonstra que os amos ou outros detentores de escravos (como atravessadores) possuíam ilicitamente seus escravos, muito possivelmente o único caminho para sustentar uma interpretação alternativa minimamente cogente do princípio do possuidor e para pôr a nu as premissas não apresentadas e, talvez, ainda não encontradas por Jaca que fundamentavam a conclusão de que eram os escravos os favorecidos por tal princípio (cf. Resolución I, n. 8).

Especificamente, a demonstração de que os amos possuíam ilicitamente seus escravos - e, logo, estavam obrigados a manumiti-los, pagálos e indenizá-los - ocorre na segunda metade do cap. II de Servi Liberi, nos parágrafos n. 31-35. Formalmente, o argumento inicia em seguida do estabelecimento da conclusão 1 , no n. 33 , pois a mesma razão que proíbe os envolvidos no tráfico de comprarem ou venderem escravos (viz:: a má-fé oriunda da não investigação) também os proíbe de possuírem. Todavia, do ponto de vista de seu conteúdo, o mesmo começa já no n. 31, iluminado por uma proposição que Moirans estabelece como diretriz para o rechaço do alegado da dúvida que favoreceria o amo ou outro detentor de escravos: "os negros têm direito a sua liberdade e estão em posse dela [in possessione eius sunt], até que por seus pecados sejam dela privados por autoridade pública" (31, p. 44), pois, ao cabo de tudo, interessa definir que o escravo é possuidor 
(possessor). A validade dessa estratégia interpretativa, no entanto, para não resultar artificiosa, depende de que noutra frente argumentativa se evidencie a nulidade dos contratos de compra e venda e dos títulos de compra a fim de mostrar que a figura do "amo possuidor" nunca existiu. Substantivamente, é essa linha argumentativa a principal para demonstrar que os amos possuíam ilicitamente seus escravos, conquanto essa linha, para fins de estratégia argumentativa, seja apenas subsidiária de uma interpretação alternativa e heterodoxa que subverte a lógica (convencional) de interpretação do princípio do possuidor em vista de favorecer os muitos escravos africanos que trabalhavam na América.

A partir do estabelecimento da conclusão 1, Moirans envida esforços para provar a posse ilícita dos amos trabalhando com quatro regras do Corpus iuris canonici, constantes no Liber VI Decretalium (lib. V, tit. 12, de regulis iuris):

Regra 82: "Presume-se que não tem boa fé quem compra contra o direito".

Regra 2: "O possuidor de má fé nunca prescreve".

Regra 4: "O pecado não é perdoado se não é restituído o que foi subtraído".

Regra 64: "As coisas feitas contra o direito devem ser consideradas como não feitas".

Em posse dessas regras, Moirans assume o papel de acusador dos amos e de todos os que retinham escravos africanos, em vista de mostrar que não havia direito capaz de justificá-los. $\mathrm{O}$ missionário faz isso mediante três passos coordenados:

(i) mostra que a responsabilização dos amos não é extemporânea e que, logo, ainda é oportuna a reclamação dos malfeitos;

(ii) indica o caminho da responsabilização e mostra as consequências teológicas da eventual não reparação dos malfeitos;

(iii) mostra a invalidade dos contratos de compra e venda celebrados.

Como Moirans está a tratar de malfeitos já havidos, estabelecer (i) justifica-se de modo evidente. Para fazê-lo, aplica as duas primeiras regras mencionadas (82 e 2) e fixa "a falta de boa-fé" como termo médio de seu silogismo. Considerando que os envolvidos no tráfico não investigavam, era manifesta a falta de boa-fé deles e, por conseguinte, era evidente que comerciavam contra o direito e que possuíam com má-fé o que haviam adquirido. Mas, nesse caso, nenhum dos amos estaria isento de responder por seus malfeitos, em razão de a má-fé nunca prescrever: "os senhores de 
escravos não têm prescrição nem podem prescrever segundo essa regra [regra 2]" (II, 33, p.48). E, por certo, ainda que de modo incipiente, verifica-se aqui a proposição de uma tese significativa: a qualquer tempo podem ser reclamados os malfeitos cometidos contra o povo africano, pois sempre, por parte dos cristãos, eram sabidos e deliberados os danos que se causavam ou, ao menos, eram assumidos os riscos pelos mesmos, e tais atos dolosos não poderiam deixar de ser responsabilizados, pois, inexistindo verdadeira boa-fé (i.e.: precedida de investigação), não poderia haver prescrição que os eximisse de prestar contas.

$\mathrm{Na}$ sequência, a responsabilização anunciada recebe um nome: restituição (restitutio), mediante o uso de mais uma regra (regra 4). Como o pecado só é perdoado por meio da restituição do que foi subtraído, segue-se que a má-fé dos amos só pode ser perdoada se eles restituírem a liberdade dos africanos por meio da manumissão, pois, se não o fizerem, ficarão sujeitos à danação (II, 33, p.48). E por isso a conclusão 2 menciona o risco da danação eterna. E, nesse ponto do argumento, a situação dos amos é esta: eles não estão isentos de responsabilidade e estão obrigados a manumitir seus escravos.

Não obstante, conquanto convenientes, essas conclusões ainda não ajudam Moirans a responder satisfatoriamente ao argumento que pretende refutar. Por isso, seu último passo consiste em impugnar a validade dos contratos de compra e venda, já que a validade da posse do escravo com base no título de compra legitimava a situação privilegiada do amo inclusive em circunstâncias de dúvida sobre a legitimidade do título de escravidão. Para proceder tal passo, Moirans não tem dificuldade, pois já estabeleceu que os compradores agiam contra o direito e com má-fé.

Se o que foi feito contra o direito deve ser considerado como "não feito" (infectum), então todos os contratos de compra e venda devem ser considerados inválidos, pois, ao violarem o direito natural, esses contratos foram injustos. Mas, nesse caso, a posse de um escravo com base num título de compra é completamente inválida. Logo, os amos não são possuidores legítimos e devem manumitir seus escravos:

\footnotetext{
Disso tudo [que se disse], segue-se que os senhores e senhoras de negros devem manumiti-los, como se não os tivessem comprado ou pago um preço [por eles], porque o contrato foi injusto, a compra e a venda foram contra o direito natural e, por conseguinte, a posse é contra a lei natural. A razão disso é que, segundo consta nas regras do direito, no livro VI, "as coisas feitas contra o direito devem ser consideradas como não feitas [infectis]". Portanto, a compra, a venda e outros contratos de negros feitos contra o direito natural devem ser tomados como não feitos [infectis]; devem ser reputados como não realizados [non facta] porque causaram injúria injusta aos negros. Enquanto se fundamenta apenas no título de compra, venda ou doação, ou em outros contratos injustos contra a liberdade natural dos negros, a posse não se sustenta nem vale. Desse modo, os
} 
injustamente possuidores estão obrigados a manumitir seus escravos, a restituir a liberdade deles e a todas as consequências derivadas disso. [...] Ao manumitirem seus escravos, os senhores estão obrigados a pagar pelos trabalhos deles e a indenizá-los (SL II, 35, p.50).

E os amos estão obrigados a tudo isso (manumissão e pagamento de salários e indenizações) não só para evitarem a danação como também, e este é um ponto importante, porque não há direito que os proteja ou dúvida que os favoreça. Destarte, fica evidente que o princípio do possuidor não favorece o amo, pois esse nunca teve posse alguma. $\mathrm{O}$ amo era apenas um falso dono. Entre amo e escravo, o único verdadeiro proprietário de algo era o escravo. Esse não perdeu sua liberdade ao ser injustamente escravizado. Ele só a teria perdido se a escravidão lhe fosse imposta como pena por seus pecados por meio de uma autoridade pública, o que, porém, não era o caso e, ipso facto, acabava por fazê-lo detentor não só do direito à liberdade como da própria posse de sua liberdade. $\mathrm{Na}$ verdade, o escravo teve sua liberdade usurpada, mas não perdeu seu direito a ela, tampouco deixou de ser seu possuidor, já que o amo, que se arvorava detê-la, em nenhum momento chegou realmente a possuí-la.

Para Moirans, as ilegalidades das escravizações e, posteriormente, dos contratos de compra e venda não chegavam a arranhar o direito natural à liberdade do africano injustamente escravizado. Mesmo encontrando-se de fato escravizado, ele não era escravo de direito. E por isso Moirans chama os africanos de servi liberi. Eles se achavam na condição de escravos, encontravamse subjugados a um amo, mas não eram escravos. Apesar das vicissitudes da condição degradante em que se encontravam, eles se mantinham livres e continuavam sendo os possuidores de sua liberdade, pois nunca chegaram a perdê-la e porque nunca chegaram a tê-la com justiça aqueles que os retinham como escravos.

Argumentando desse modo, Moirans entendia que as conclusões 2-3 seguiam-se como consequência das ilegalidades por trás das escravizações e dos contratos de compra e venda e, sobretudo, como consequência da invalidade não só desses contratos como dos títulos de posse, pois, sendo nulos os contratos devido ao vício de origem havido nas escravizações, restava claro que a liberdade devia ser restituída aos escravos, mediante a manumissão em conjunto com pagamentos pelos serviços prestados e, também, à guisa de indenização.

Em meio a esse discurso sobre o tráfico, além da evidente defesa da liberdade natural dos africanos, subjaz uma severa crítica às corriqueiras alegações de boa-fé e de ignorância nas compras, uma vez que é mormente na denúncia da falta de cogência dessas alegações - mediante a detecção de que as 
consciências dos envolvidos eram vencivelmente errôneas - que Moirans estabelece as conclusões 1, 2 e 3 . Não obstante, a crítica a tais alegações constitui apenas uma parte do arrazoado de Moirans contra o tráfico. Ao missionário ainda restava combater as alegações da incomunicabilidade entre dúvida teórica e prática e da solvência da dúvida mediante opinião provável.

\subsection{Matéria grave como a morte civil exige certeza teórica, dispensa razões prováveis}

As alegações da incomunicabilidade entre as dúvidas teórica e prática e do recurso à opinião provável concernem, ambas, ao tópico da consciência certa - i.e.: a consciência que age livre de dúvida e seguindo pelo menos uma certeza prática. Por isso, abordarei a crítica de Moirans a tais alegações apresentando-as em conjunto.

Essencialmente, sua crítica decorre de uma posição teórica pouco comum, viæ: uma posição de condenação de qualquer ação em circunstância de dúvida - quer teórica, quer prática -, lastreada no entendimento de que a consciência certa não estaria salvaguardada mediante certeza prática, bem como, conforme notou González, na visão de que se fazia necessário substituir a certeza prática pela "certeza real e objetiva" (2007a, p.501).

Com efeito, mais do que opor-se ao engendramento de certeza prática mediante opiniões prováveis, Moirans opõe-se ao próprio engendramento dessa certeza. Quando aponta no cap. II que ninguém pode comprar negros "a menos que esteja certo sobre a justa escravidão" (31, p.44) e "a menos que os títulos de justa escravidão sejam justificados e verificados" (32, p.46), Moirans está se referindo à certeza teórica. O ponto não é sobre haver certeza quanto a passar (ou não) à ação, mas sobre haver certeza quanto à justiça da escravidão, certeza que, na visão do missionário, deveria ser requerida não só daqueles que compravam escravos na África como também daqueles que compravam e possuíam escravos na América (33, p. 46). E embora houvesse um entendimento de que a investigação dos títulos de escravidão por parte desses últimos podia ser vista com outros olhos e até com alguma condescendência, devido à dificuldade que esses teriam na apuração da licitude dos títulos ${ }^{25}$, Moirans exige sem transigir que todos os envolvidos no

25 Sánchez entendia que a investigação dos títulos de escravidão não se fazia obrigatória na segunda compra por já não ser mais possivel conhecer a licitude dos mesmos (Consilia I, cap. 1, dub. 4, n. 13). Essa é, porém, apenas uma de várias posições condescendentes quanto à certificação da licitude dos títulos de escravidão no tocante à segunda compra. Os autores que consentiam com a alegação de boa-fé por parte dos compradores da segunda compra e os que concediam que o inquérito infrutifero favorecia os amos, todos eles reforçavam o partido que entendia que era preciso um olhar diferenciado para a segunda compra. 
tráfico deveriam estar certos da justiça dos títulos de escravidão, independente do lugar onde comprassem ou de sua posição na cadeia de compras.

A exigência de certeza teórica fica evidenciada no cap. II quando Moirans procede uma aplicação do princípio tuciorista para responder uma objeção (do "partido escravista") de que só seriam possuídos injustamente os africanos raptados por força e fraude e capturados com dolo, mas não os comprados de quem já os tivesse como escravos:

Respondo à objeção da seguinte forma: os próprios que alegam essa objeção são
julgados e condenados por suas palavras à medida que admitem que alguns são
apanhados com força e dolo, capturados com fraude e vendidos como escravos.
Logo, ninguém pode, com consciência segura, comprar um escravo
transportado. A consequência é evidente: desconhecendo-se quem foi apanhado
injustamente, para evitar comprar um escravo capturado com força, dolo e
fraude, não se pode comprar nenhum, pois quem ama o perigo perece no
perigo. Portanto, com tal dúvida ninguém pode comprar [in tali dubio nemo potest
emere], pois não é lícito agir com dúvida [quia in dubio non licet operari], como bem
disse Mercado. Se alguém soubesse da existência de mercadorias subtraídas por
furto ou rapina no navio do viajante que chega ao porto, mesmo que muitas
fossem possuídas com justiça pelo mercador e pudessem com justiça ser
vendidas, ninguém, contudo, poderia adquiri-las ou comprá-las do mercador por
causa do perigo de comprar coisa alheia, subtraída por furto ou rapina.
Semelhantemente, ninguém pode comprar, com consciência segura, escravos da
África sabendo que entre eles existem escravos subtraídos por furto e
capturados com força, fraude e dolo. E isso é um princípio da moral. Portanto, a
partir das próprias palavras dos que proferem tal objeção, eu julgo e condeno
todos que a apresentam para justificarem as desculpas nos pecados (SL II, 32,
p.46).

Embora tal resposta se fundamente no conselho tuciorista de produção de certeza prática mediante a detecção do curso de ação mais seguro, é notável a ênfase à impossibilidade de conhecimento sobre quem foi capturado com justiça, pois essa impossibilidade produz a impossibilidade de ação, o que significa que há comunicação entre os intelectos teórico e prático não só nos casos de certeza teórica como também nos de dúvida teórica.

O mais relevante da passagem é o modo como Moirans se refere à situação de dúvida. Em cada uma das menções à dúvida, o ablativo in (tali) dubio apresenta uma semântica equívoca, possivelmente adotada de modo deliberado com vistas a sustentar uma tese exigente e rigorosa sobre os requisitos para se passar à ação no tocante a uma matéria tão moralmente controversa como o tráfico.

Do ponto de vista do contexto inteiro da resposta, a primeira menção à dúvida (in tali dubio) é respectiva à dúvida teórica sobre quem foi capturado

Para detalhes sobre as visões (condescendentes) dos autores sobre a segunda compra, cf., e.g.: Añoveros (2000, p.126-128); Andrés-Gallego e Añoveros (2002, p.150-156). 
com justiça. De outra parte, do ponto de vista específico da oração in tali dubio nemo potest emere, a menção à dúvida é respectiva à dúvida prática, em razão de a situação de dúvida representar obstáculo à ação. Quanto à segunda menção à dúvida, do ponto de vista específico da oração in dubio non licet operari, novamente o ablativo in dubio remete à dúvida prática. Entrementes, não se podendo esquecer o contexto amplo da resposta, in dubio recupera a semântica de dúvida teórica da oração precedente, dado que o problema subjacente na resposta é a dificuldade ou impossibilidade de discriminar mercadorias lícitas de ilícitas.

Embora não seja impossível que Moirans tenha sido descuidado, é improvável que isso tenha ocorrido, mormente quando a opção deliberada pelo não uso de qualificativos para falar da dúvida lhe resulta útil para condenar o tráfico. Seguramente, Moirans estava ciente de que in tali dubio nemo potest emere era uma proposição discutível e sabia que in dubio non licet operari jamais poderia ser uma proposição verdadeira sem um qualificativo no ablativo. Todavia, mesmo assim as apresenta como verdadeiras desejoso de fazer convencer o leitor de que, pelo menos no tocante à matéria do tráfico, o uso de qualificativos para a dúvida deveria ser evitado, por ser uma matéria sobre a qual não deveria haver nenhum tipo de dúvida, não só para se preservar a consciência dos envolvidos como também, e acima de tudo, para se evitar violar o direito natural dos africanos à liberdade.

Rigorosamente falando, embora fosse desejável ter o conhecimento sobre a justiça da escravidão, isso não chegava a representar obstáculo à ação, e principalmente tratando-se dos compradores de fora da África - com poucas chances de procederem inquéritos frutíferos sobre a licitude dos títulos. $\mathrm{O}$ impedimento propriamente dito para se passar à ação residia na presença de dúvida prática. No parecer de Moirans, contudo, esse entendimento, no trato das questões morais atinentes ao tráfico, não era senão sintoma de um velado laxismo contra o qual era preciso se levantar para evitar a manutenção de uma mentalidade que autorizava injustiças salvaguardando a consciência de seus autores. E, para tanto, estabelecer que quaisquer tipos de dúvida estariam vedadas acabava se revelando uma estratégia conveniente.

É inegável que o tuciorismo se revelava oportuno para condenar o tráfico. A citação feita acima mostra isso. Não obstante, para Moirans, a questão mais importante era afastar-se dos sistemas morais para levar a discussão sobre o tráfico para outro âmbito. Em vez de discuti-lo apenas no tocante à consciência e à subjetividade do agente, era preciso discuti-lo sobretudo no âmbito das violações perpetradas contra os africanos. E daí a necessidade de reivindicar certeza teórica, exigindo uma prova propriamente dita (i.e.: os títulos de justa escravidão) ao invés de alegações circunstanciais - 
como, e.g., as apresentadas por Avendaño, sobre como as autoridades reais e eclesiásticas procediam no tocante ao tráfico ou sobre a pertinência do mesmo para a América e não impertinência para indivíduos tão vis como os africanos (Thesaurus IX, cap. 12, §8, n.204).

Essa certeza teórica suposta por Moirans está totalmente em linha com a "ciência certa" (ciencia cierta) de que falara Jaca em sua Resolución, obra da qual Moirans extrai argumentos ainda embrionários para desenvolvê-los em detalhes. Segundo Jaca, "como a escravidão é pena certa imposta pelo direito das gentes, é certo que no tocante aos que devem padecer tal agravo e castigo não deve haver escrúpulo, mas ciência certa do mesmo" (I, n. 13, p.15).

O ponto levantado por Jaca realça a objetividade do fato, não a subjetividade da performance do agente formando consciência. E isso é levado a sério por Moirans, sobretudo porque ele estava ciente de que a mercadoria em questão não eram os tecidos de que falara Mercado (Summa II, cap. 20), mas seres humanos que, por mais vis que fossem considerados, detinham direitos. Tratando-se de seres humanos e sendo a escravidão a própria "morte civil" (mors civilis) - e, por isso, o segundo pior mal que alguém pode padecer, só não pior do que a morte física (SL II, 27-28, p.38s) -, a objetividade do fato sobrepõe-se à subjetividade da consciência e certeza teórica passa a ser maximamente requerida.

Por tudo isso, resulta evidente a discordância de Moirans com a alegação de seguir o provável. Sendo o probabilismo um sistema útil para ajudar no engendramento de certeza prática, o mesmo era por si inadequado para ser requisitado no exame da matéria do tráfico, e mormente após a recente condenação pelo Papa Inocêncio XI (1676-1689) de proposições morais que aludiam ao seguimento do provável $^{26}$.

Apesar de o probabilismo encontrar-se um tanto abalado devido à maré de contestações sobrevinda na segunda metade do séc. XVII, Moirans dedica considerável atenção para criticar o recurso às opiniões prováveis em

${ }^{26} \mathrm{Em} 2$ de Março de 1679, 65 proposições morais foram censuradas por seu cunho laxista. Dessas proposições, as quatro primeiras aludiam ao seguimento do provável, mas especialmente a segunda e a terceira - viz.: "Il. Julgo, com probabilidade, que o juiz pode julgar com sua própria opinião, ainda que menos provável; III. Geralmente, quando fazemos algo confiando na probabilidade, intrínseca ou extrínseca e ainda que tênue, enquanto não saimos dos limites da probabilidade, agimos sempre prudentemente" (Decret de N. S. P. le Pape Innocent XI contre plusieurs propositions de morale) - revelavam-se importantes para Moirans, que fez questão de citá-las para reprovar o recurso a opiniões prováveis - cf.: $S L$ VIII, 89, p. 136; $\mathrm{XI}, 113$, p. 170. Antes da condenação de Inocêncio XI, já Alexandre VII (1655-1667), em 1665-1666, havia condenado proposições que recomendavam o seguimento do provável. Para detalhes sobre essas condenações pontifícias e outras informações sobre as contestações ao probabilismo na segunda metade do séc. XVII, cf., e.g.: CONCINA (1743, t. 1, p. 34-87); MADRE DE DIOS (1761, t. 2, p. 357-426); LÁRRAGA (1833, p. 534-577); DEMAN (1936, col. 501-558). 
razão de alguns autores jesuítas o terem requisitado para sustentarem que o caminho do provável seria suficiente para desfazer as dúvidas dos envolvidos no tráfico.

Por ocasião das disputas com autores adversários, nos caps. VI-XI de Servi Liberi, Moirans por três vezes questiona o seguimento de razões prováveis (VII, 80; VIII, 89; XI, 113), rivalizando sobretudo com Avendaño ${ }^{27}$, que afirmava não ser necessário que o título de escravidão constasse com plena clareza $^{28}$ e que entendia que a não condenação aberta do tráfico por parte de alguns doutores era indício de que o mesmo se justificava ${ }^{29}$.

Divergindo de Avendaño, Moirans sustenta que milita contra o uso de razões prováveis o fato de que essas razões nunca evidenciam a certeza necessária para a justificação do título de escravidão:

\footnotetext{
Sendo a liberdade de direito natural e estando cada ser humano em posse de sua liberdade, não se pode tirá-la do homem senão com título justificado e verificado de justa escravidão. No entanto, enquanto existam razões apenas prováveis [tantum probabiles], e não certas [et non certae], o título não está verificado e justificado como se requer. Portanto, a menos que se esteja convicto e que haja razões certas sobre o delito, nunca é lícito condenar um réu a morte ( $S L$ VIII, 88, p. 134).
}

A oposição entre razões probabiles e certae indica que somente certeza teórica pode justificar os títulos de escravidão e realça que o probabilismo é impróprio para ser requisitado no tocante ao tema do tráfico por sua incompatibilidade para ajudar na resolução da dificuldade de fundo por trás do mesmo: o conhecimento da legitimidade da escravidão. A essência do probabilismo são as opiniões. A essência da resolução do problema do tráfico, na visão de Moirans, é a obtenção de certeza. Todavia, essas duas realidades,

\footnotetext{
${ }_{27}$ Moirans também rivaliza com Sánchez, embora este tenha sustentado uma visão probabiliorista para dirimir a dúvida sobre a legitimidade dos títulos de escravidão (Consilia I, cap. 1, dub. 4, n. 15). Moirans, contudo, não faz distinção entre visão probabilista e probabiliorista. Como seu ponto concerne à obtenção de certeza teórica, pouco importa defender a necessidade de "razões mais prováveis". A disputa com Sánchez é a que ocorre em VII, 80.

${ }^{28}$ Cf.: "Não é necessário que o título de escravidão seja mais claro que a luz para se permitir a escravidão [...]. De fato, para se favorecer a negociação na medida do possível salvaguardando-se a consciência, não é certamente necessário que o título seja mais claro que a luz. É suficiente que seja provável. Com efeito, pode-se sustentar, com consciência segura, uma opinião provável sobre um título de escravidão, assim como sobre outros assuntos e sobre a guerra, segundo é opinião bastante comum entre os contemporâneos" (Thesaurus IX, cap. 12, §8, n.191, p.326s). Essa posição ocorre em comentário a uma proposição de Molina segundo a qual o título de justa escravidão deveria constar de modo mais claro que a luz (De iustitia Il, d.35, n.19).

${ }^{29}$ Cf.: "A compra nas Índias e na Europa pode justificar-se de algum modo. Em primeiro lugar, porque alguns doutores, ainda que inconsequentemente com suas próprias doutrinas, afirmam que ela não é abertamente condenável. Ao contrário, inclusive a favorecem, como os padres Molina, Rebelo, Palao, Fragoso, Fagúndez e outros" (Thesaurus IX, cap. 12, §8, n.204, p.330).
} 
opiniões e certezas, são tão díspares que resultam inconciliáveis, por ser realmente impossível, com o mínimo senso de razoabilidade, requisitar opiniões para tratar de uma matéria exigente de certeza.

Não obstante, a principal incompatibilidade do probabilismo com a matéria do tráfico é que a aproximação de realidades díspares como opinião e certeza gera inconveniência para a manutenção da justiça, em razão de o ponto fundamental do drama da escravidão negra não ser a salvaguarda das consciências dos envolvidos nas compras e vendas de escravos, mas os danos perpetrados contra os muitos africanos injustamente escravizados.

Para Moirans, a matéria inteira do tráfico era extremamente grave. Ela envolvia violações não só físicas como de direitos, fraudes de toda espécie e, o pior de tudo, dano (damnum). O probabilismo, porém, com suas opiniões prováveis, revelava-se estéril para atacar o problema dos danos: "Com muito mais razão, não se deve seguir a probabilidade quando isso leva a grave dano de um terceiro, não só de um, mas de tantos milhões de escravos" (SL XI, 113 , p. 170). Na verdade, o probabilismo poderia inclusive potencializar a ocorrência de danos, sendo ele próprio agravante de uma matéria por demais grave.

Para evitar esse cenário de agravamento de injustiças e danos, Moirans entende que a busca de certeza teórica devia ser o imperativo moral dos envolvidos no tráfico. Por isso, aponta que não se pode seguir uma opinião menos provável no tocante a uma causa que envolve danos a milhões de escravos (SL XI, 113) e assevera que, em causas desse tipo (que são causas de sangue), deve haver "sentença certa":

De fato, diz-se que “Toda iniquidade, opressão e injustiça é juízo de sangue; embora não mates com a espada, destróis, todavia, com a vontade" [Decretum Gratiani, pars II, causa 33, q. 3, dist. 1, cap. 25]. Uma vez que a iniquidade, a opressão, a injustiça e a injúria feita aos negros vai contra o direito natural à liberdade, trata-se de causa de sangue, de causa de grave dano a terceiro, de causa de morte civil, de causa contra o direito natural à liberdade, trata-se de matéria em que deve haver sentença certa [certa sententia] e em que a causa da justa escravidão deve ser mais clara que a luz [...] (SL XI, 113, p. 172).

Em que pese o argumento da incompatibilidade do probabilismo com o tema do tráfico ser o mais importante para refutar o caminho do provável e propugnar a necessidade de certeza teórica, Moirans também fez questão de apontar que militavam contra o probabilismo outras duas razões: o fato de a posição dos doutores, referida por Avendaño, não atender a um requisito necessário para chegar a ser provável; e o fato de proposições prováveis terem sido alvo de recente condenação pontifícia.

Sempre lendo com atenção o Thesaurus indicus, Moirans levou a sério o que Avendaño dissera sobre alguns doutores não terem condenado o tráfico, 
"ainda que inconsequentemente [inconsequenter] com suas próprias doutrinas", e viu nessa ressalva indício de que a posição tolerante ou favorável ao tráfico não se configurava como provável e digna de ser seguida.

Fundamentalmente, segundo estabelecido por Medina, seria provável a opinião que: (a) fosse defendida por homens sábios; (b) fosse confirmada por excelentes argumentos; e (c) estivesse de acordo com a reta razão e a estima de homens prudentes e sábios (In Ia-IIae, q. 19, a. 6). Não obstante, sendo inconsequentemente (inconsequenter) defendida, a posição dos doutores não atendia pelo menos ao critério (b) e, logo, estava reprovada.

O próprio Moirans não chega a nomear a autoridade que o ajuda a refutar a posição de Avendaño, mas é evidente pelo teor de seu argumento que ele testou essa posição à luz dos critérios recém mencionados:

Aqueles doutores [que Avendaño cita] de modo algum fazem provável essa opinião [que justifica o tráfico], visto que falam inconsequentemente com sua doutrina e que essa é falsa e contra seus princípios. Semelhantemente, o próprio Avendaño, sem explicação, propôs justificações ao tráfico contra sua doutrina, pois, ao dizer ter lutado pela verdade e a justiça (em páginas anteriores), segue-se que falou inconsequentemente [...]. Ao dizer que aqueles doutores favorecem esta negociação injusta após ter provado que de modo algum a favoreceram, Avendaño contradisse a si mesmo, tal como outros. Portanto, tais doutores não criam nenhuma probabilidade. Pelo contrário, estão contra a negociação (SL XI, 113, p.170).

Por outro lado, mesmo desconsiderando-se esse problema interno na posição dos doutores e concedendo-se a eventual probabilidade dessa posição, sequer assim a justificação do tráfico seria defensável no contexto então adverso ao probabilismo:

Ainda que suposto, mas não concedido, que os doutores criassem probabilidade, digo que de modo algum poder-se-ia seguir uma opinião que tivesse alguma probabilidade, segundo consta nas proposições condenadas por Inocêncio XI. $\mathrm{Na}$ terceira, e.g., consta o seguinte: "Geralmente, quando fazemos algo confiando na probabilidade, intrínseca ou extrínseca e ainda que tênue, enquanto não saímos dos limites da probabilidade, agimos sempre prudentemente". Estando condenada essa proposição, não se pode seguir a opinião em favor da negociação, ainda que tenha alguma probabilidade (SL XI, 113, p.170).

Mais do que um argumento de autoridade, o que leva Moirans a rechaçar o emprego de opiniões prováveis e a exigir razões certas é sua divergência conceitual com o probabilismo e, mais amplamente, com qualquer seguimento do provável no tocante ao tráfico, bem como sua metodologia analítica que não dissocia o discurso sobre os títulos de escravidão do discurso sobre o tráfico. Ao não promover tal dissociação, Moirans consegue estabelecer uma estratégia argumentativa que lhe permite refutar não só o 
argumento que alegava a correção no seguimento do provável como também outros argumentos fundados em alegações autorizadoras da manutenção do tráfico. Essa estratégia resulta eficaz porque Moirans traz à tona a grande dificuldade por trás do tema da escravidão negra: as injustiças das escravizações, e leva essa dificuldade para dentro do discurso sobre o tráfico. Embora tivesse sido escamoteada por alguns autores, essa dificuldade sempre esteve ligada ao tema do tráfico. O que Moirans fez foi perceber isso e notar que essa dificuldade, se não fosse negligenciada, tornava impossível um posicionamento tolerante ou favorável ao tráfico, pois não haveria argumento fundamentado nas alegações mencionadas que resistisse.

Frente a isso, a salvaguarda da consciência dos envolvidos no tráfico restava realmente pouco relevante quando milhões de escravos, sendo lesados em seu direito natural à liberdade, convertiam-se em vítimas de graves danos. Frente a isso, exigir certeza teórica e verificação dos títulos de escravidão, refutar o uso de razões prováveis e condenar alegações de ignorância e boa-fé era simplesmente dizer e exigir o óbvio.

\section{Conclusão}

Várias coisas distinguem Moirans de outros autores que escreveram sobre a escravidão negra nos sécs. XVI-XVII. O fato de Moirans ter elaborado um tratado específico sobre o tema e ter assumido a tarefa de advogado dos escravos são alguns elementos distintivos. Não obstante, o principal elemento de diferenciação é sua visão sobre o tráfico.

O discurso de Moirans sobre o tráfico é combativo e intrépido. Quer, sem transigir, provar que o tráfico deve parar e que medidas corretivas devem ser implementadas. Ademais, é invariavelmente não neutro e militante. Não se trata de um discurso professoral ou isento. Moirans não ombreia com um Vitoria ou com um Molina. Entretanto, trata-se de um discurso agudo, arguto, legítimo de ser feito e digno de ser lido. A falta de isenção não prejudica sua lógica, tampouco o engajamento desmerece sua legitimidade.

Fundamentalmente, esse discurso realiza movimentos que o diferenciam dos discursos de outros autores: ele leva para dentro do exame do tráfico a dificuldade fundamental por trás do tema inteiro da escravidão negra, viæ: o problema da justiça das escravizações, adotando, assim, uma distinta perspectiva metodológica de análise do tema; e ele se afasta do casuísmo característico da época ao desconsiderar o tema da produção de certeza prática e ao introduzir um vocabulário, uma rivalidade com o probabilismo e exigências a serem cumpridas pelos envolvidos no tráfico à medida que trabalha com o conceito de certeza teórica. 
Dado o intento de Moirans de advogar pelos servi liberi, a relevância do primeiro movimento é que esse não só mostra o vício de origem das escravizações como põe a nu o problema da perpetuação das injustiças havidas a partir da análise das compras de escravos apenas do ponto de vista da consciência dos envolvidos. É verdade que esse movimento, ainda que sutilmente, fora tentado por Mercado. No entanto, com Moirans ele é efetivamente realizado e tem peso em sua defesa dos servi liberi, pois mostra o quanto eles já haviam sido lesados e permaneciam sendo lesados por se entender que o problema dos vícios das escravizações não se comunicava com o tema das compras de escravos.

Quanto ao segundo movimento, ele era consequência do primeiro e resultado do convencimento de Moirans de que a casuística havia se convertido num terreno propício para a justificação do tráfico e de que era preciso remover, tanto quanto possível e necessário, o tema do tráfico das discussões dos casos de consciência duvidosa. E a impugnação de alegações legítimas da teologia moral mostra isso claramente, pois na base da refutação de cada uma das alegações Moirans trabalha, implícita ou explicitamente, com o conceito de certeza teórica.

De um lado, as alegações da ignorância e da boa-fé eram impossíveis porque ninguém efetivamente investigava coisa alguma. De outro, as alegações da incomunicabilidade entre as dúvidas teórica e prática e de seguir o provável eram impossíveis porque, pelo menos no tocante a uma matéria tão grave como a morte civil, não seria correto passar a ação com dúvida teórica ou valendo-se de razões prováveis para dirimir tal dúvida.

Não obstante, deve-se notar que Moirans só se afastou do casuísmo e dos sistemas morais enquanto esses justificavam a manutenção do tráfico. Embora a certeza teórica lhe fosse cara, Moirans não viu problema em contentar-se com certeza prática no âmbito do tuciorismo, tampouco em admitir a possibilidade da dúvida se essa favorecesse o escravo. Isso significa que o afastamento de Moirans em relação ao casuísmo e aos sistemas morais ocorre apenas enquanto isso é necessário para uma condenação enfática do tráfico.

É inegável que a exigência de certeza teórica é uma tese forte de Moirans. Ela traz à tona o problema da justiça das escravizações e isso lhe permite condenar o tráfico. Tal exigência, porém, não é mais importante do que condenar o tráfico. Sendo possível condená-lo deixando-a de lado ou valendo-se do casuísmo e dos sistemas morais, isso deveria ser feito. No parecer de Moirans, havendo um sistema moral capaz de obliterar a ação e um princípio capaz de favorecer o escravo, tal sistema e tal princípio não deveriam ser preteridos, pois poderiam funcionar como adjuvantes na causa antiescravista. Ao fim de tudo, o 
que realmente importava para Moirans era exigir o fim do tráfico e afirmar a liberdade daqueles que a tiveram negada.

\section{Referências}

\section{Fontes primárias}

ALFONSO X. Las Siete Partidas. Madrid: Imprenta Real, 1807. 3 t.

AQUINO, T. Corpus Thomisticum: Opera Omnia. Ed. E. Alarcón. Pamplona:

UNAV, 2000. Disponível em: < http:/ /www.corpusthomisticum.org>. Acesso: 4 jun. 2017.

AUGUSTINUS. Opera Omnia. In: Patrologiae Cursus Completus. Series Latina. Ed. J.-P. Migne. Parisiis, 1845-1849. t. 32-47.

AVENDAÑO, D. Thesaurus indicus. Antuerpiae: Iacobum Meursium, 1668. t. 1.

FRIEDBERG, A. (Ed.). Corpus iuris canonici. Lipsiae: Bernhardi Tachnitz, 18791881. 2 v.

INNOCENT XI. Decret de N. S. P. le Pape Innocent XI contre plusieurs propositions de morale. Rome: Chambre Apostolique, 1679.

JACA, F. J. Resolución sobre la libertad de los negros y sus originarios. Ed. M.

González. Madrid: CSIC, 2002.

KRUEGER, P.; MOMMSEN, T. (Ed.). Corpus iuris civilis. Berolini:

Weidmannos, 1889. v. 1.

LAS CASAS, B. Historia de las Indias. Madrid: Miguel Ginesta, 1875. 3t.

MEDINA, B. Expositio in Primam Secundae. Salmanticae: Mathiae Gastij, 1582.

MERCADO, T. Summa de tratos y contratos. Sevilla: Fernando Diaz, 1587.

MOIRANS, E. Siervos Libres. Ed. M. González. Madrid: CSIC, 2007.

. Siervos Libres. In: GARCÍA, J. Dos Defensores de los Esclavos Negros en el

Siglo XV II. Maracaibo: Biblioteca Corpozulia; Caracas: UCAB, 1982. p. 179298.

MOLINAE, L. De iustitia et iure. Coloniae Allobrogun: Marci-Michaelis Bousquet, 1733. t. 1.

REBELLO, F. Opus de obligationibus iustitiae. Lugduni: Horatii Cardon, 1608.

S. JOSEPH, A. Compendium Salmanticense. Romae: Benedictum Francesi, 1779. 2 t. 
SALON, B. Commentariorum in disputationem de iustitia. Venetiis: Damianum Zenarium, 1592.

SANCHEZ, T. Consilia seu opuscula moralia. Lugduni: Iacobi Prost, 1634. t. 1.

SANDOVAL, A. De instauranda Aethiopum salute. Ed. A. Valtierra. Bogotá: Biblioteca de la Presidencia de Colombia, 1956.

SOTO, D. De iustitia et iure. Salmanticae: Andreas a Portonariis, 1553.

. De dubio et opinione. In: O’REILLY, F. Duda y Opinión. Pamplona:

UNAV, 2006. p. 52-63.

1570 .

. De ratione tegendi et detegendi secretum. Salmanticae: Ioanes B. Terranova,

SUAREZ, F. De bonitate et malitia. De charitate. In: - Opera Omnia.

Ed. M André, C. Berton. Parisiis: Vivès, 1856-1858. t. 4, p. 274-454; t. 12, p. 632-763.

VITORIA, F. Appendix A: Four Letters on Political Matters. Letter 2: To Fray Bernardino de Vique, OP. In: . Political Writings. Ed. A. Pagden, J. Lawrance. Cambridge: Cambridge University Press, 1991. p. 334-335.

. El tráfico de esclavos realizado por los portugueses: Fragmento de una carta al padre Bernardino de Vique. In: - Relecciones sobre los Indios y el Derecho de Guerra. Trad. A. Pirotto. 3. ed. Madrid: Espasa-Calpe, 1975. p. 22-24. . De indis. De iure belli. In: - Obras de Francisco de Vitoria. Ed. T. Urdánoz. Madrid: BAC, 1960. p. 641-726.810-858.

\section{Bibliografia secundária}

ANDRÉS-GALLEGO, J.; AÑOVEROS, J. M. G. La Iglesia y la Esclavitud de los Negros. Pamplona: EUNSA, 2002.

ANDRÉS-GALLEGO, J. La Esclavitud en la América española. Madrid: Encuentro, 2005.

AÑOVEROS, J. M. G. Luis de Molina y la Esclavitud de los Negros Africanos en el siglo XVI. Revista de Indias, v. 60, n. 219, p. 307-329, 2000.

Los argumentos de la Esclavitud. In: ANDRÉS-GALLEGO, J.

(Coord.). Nuevas Aportaciones a la Historia Jurídica de Iberoamérica. Madrid: Fundación Histórica Tavera; Digibis Publicaciones Digitales; Fundación Hernando Larramendi, 2000.

ARAMINI, M. Introduzione alla Teologia morale. 3. ed. Milano: Giuffrè, 2010. 
ASTRAIN, A. Historia de la Compañia de Jesús en la asistencia de España. Madrid: Administración de Razón y Fe, 1920. t. 6.

BEUCHOT, M. La querella de la Conquista. 3. ed. México, DF: Siglo XXI, 2004.

BRETZKE, J. Consecrated Phrases: A Latin Theological Dictionary. 3. ed.

Collegeville, MN: Liturgical Press, 2013.

CÁRDENAS, E. La Ética Cristiana y la Esclavitud de los Negros. Theologica Xaveriana, n. 55, p. 227-257, 1980.

CONCINA, D. Della Storia del Probabilismo, e del Rigorismo. Lucca: Occhi, 1743. $2 \mathrm{t}$.

CUlleton, A. Tomás de Mercado on Slavery. Patristica et Mediaevalia, v. 36, p. 29-38, 2015.

DEMAN, T. Probabilisme. In: Dictionnaire de Théologie Catholique. Paris:

Letouzey et Ané, 1936. t. 13/1, col. 417-619.

DONOSO, J. Diccionario Teolójico, Canónico, Jurídico, Litúrjïco, Bíblico, etc.

Valparaiso: Imprenta i Librería del Mercurio, 1855-1859. 4 t.

DUBLANCHY, E. Bonne foi. In: Dictionnaire de Théologie Catholique. Paris: Letouzey et Ané, 1910. t. 2/1, col. 1009-1020.

DUTILLEUL, J. Esclavage. In: Dictionnaire de Théologie Catholique. Paris: Letouzey et Ané, 1913. t. 5/1, col. 457-520.

GARCÍA, J. Dos Defensores de los Esclavos Negros en el Siglo XV TI. Maracaibo: Biblioteca Corpozulia; Caracas: UCAB, 1982.

GONZÁLEZ, M. A. P. Aportación antiesclavista en tierras de Indias, a fines del siglo XVII. In: MURILLO, I. (Ed.). El Pensamiento Hispánico en América: Siglos XVI-XX. Salamanca: UPSA, 2007a. p. 489-530.

. Doctrina antiesclavista de Epifanio de Moirans en su Servi Liberi. Naturaleza y Gracia, v. 52, n. 2, p. 279-327, 2005.

. Epifanio de Moirans: misionero capuchino y antiesclavista. Collectanea Franciscana, n. 74, p. 111-145, 2004.

. Estudio Preliminar. In: JACA, F. J. Resolución sobre la libertad de los negros y sus originarios. Madrid: CSIC, 2002. p. xxi-xcviii.

. Estudio Preliminar. In: MOIRANS, E. Siervos Libres. Madrid: CSIC, 2007b. p. xv-lxxv.

GUY, A. Historia de la Filosofía Española. Trad. A. Sánchez. Barcelona: Anthropos, 1985. Título original: Histoire de la Philosophie Espagnole. 
HÖFFNER, J. La Ética Colonial Española del Siglo de Oro: Cristianismo y Dignidad Humana. Trad. F. Caballero. Madrid: Cultura Hispánica, 1957. Título original: Christentum und Menschenwürde: Das Anliegen der spanischen Kolonialethik im Goldenen Zeitalter.

KOCH, A.; PREUSS, A. A Handbook of Moral Theology. 3. ed. St. Louis; London: Herder Book, 1925-1928. 3 v.

LÁRRAGA, F. Prontuario de la Teología Moral. Barcelona: Sierra y Martí, 1833.

MADRE DE DIOS, V. Fuero de la Conciencia. Madrid: Andrès Ortega, 1761. 2 t.

MANGENOT, E. Ignorance. In: Dictionnaire de Théologie Catholique. Paris:

Letouzey et Ané, 1922. t. 7/1, col. 731-740.

MAURICIO, D. A Universidade de Évora e a Escravatura. Didaskalia, n. 7, p. 153-200, 1977.

MOLIEN, A.; AMANN, E. Laxisme. In: Dictionnaire de Théologie Catholique.

Paris: Letouze et Ané, 1926. t. 9/1, col. 37-86.

O’REILLY, F. Duda y Opinión. Pamplona: UNAV, 2006.

PAGDEN, A. The Fall of Natural Man. Cambridge: Cambridge University Press, 1986.

PICH, R. Alonso de Sandoval and the Ideology of Black Slavery. Patristica et Mediaevalia, n. 36, p. 51-74, 2015.

PICH, R. et al. Diego de Avendaño sobre a Opinião Provável. Mediaevalia, n. 31, p. 135-181, 2012.

PICH, R.; CUlLETON, A.; STORCK, A. (Ed.). Patristica et Mediaevalia, Buenos Aires, n. 36, 2015.

SARANYANA, J.-I. La Filosofía Medieval. Desde sus Orígenes Patrísticos hasta la Escolástica Barroca. Pamplona: EUNSA, 2003.

SARANYANA, J.-I. (Dir.); GRAU, C.-J. (Coord.). Teología em América Latina. Desde los Orígenes a la Guerra de Sucesión (1493-1715). Madrid:

Iberoamericana; Frankfurt: Vervuert, 1999. v. 1. - Teología en América Latina. Escolástica Barroca, Ilustración y

Preparación de la Independencia (1665-1810). Madrid: Iberoamericana; Frankfurt: Vervuert, 2005. v. 2/1.

SCHÜSSLER, R. On the Anatomy of Probabilism. In: KRAYE, J.;

SAARINEN, R. Moral Philosophy on the Threshold of Modernity. Dordrecht: Springer, 2005. p. 91-114. 
SOLANA, M. Historia de la Filosofía Española: Época del Renacimiento (Siglo XVI). Madrid: Real Academia de Ciencias, 1940-1941. 3 t.

VACANT, A.; MANGENOT, E. (Ed.). Dictionnaire de Théologie Catholique.

Paris: Letouzey et Ané, 1902-1950. 15 t.

VARAS, L. S. Teoría Esclavista de Tomás de Mercado. Ciencia Tomista, t. 116, n. 379, p. 317-332, 1989.

VILAR, E. La postura de la Iglesia frente a la Esclavitud. Siglos XVI y XVII. In: SOLANO, F.; GUIMERÁ, A. (Ed.). Esclavitudy Derechos Humanos. Madrid: CSIC, 1986.

E-mail: fernandodoca@ifsul.edu.br

Recebido: 06/2017

Aprovado: 10/2017 